CNS Spectrums (2016), 21, 143-161. C Cambridge University Press 2015. The online version of this article is published within an Open Access environment subject to the conditions of the Creative Commons Attribution-NonCommercial-ShareAlike licence <http://creativecommons.org/licenses/by-nc-sa/3.0/ > . The written permission of Cambridge University Press must be obtained for commercial re-use.

doi:10.1017/S1092852915000425

\title{
Effects of serotonin in the hippocampus: how SSRIs and multimodal antidepressants might regulate pyramidal cell function
}

\author{
Elena Dale, ' *Alan L. Pehrson, 'Theepica Jeyarajah, ' Yan Li, 'Steven C. Leiser, ' \\ Gennady Smagin, ' Christina K. Olsen, ${ }^{2}$ and Connie Sanchez'
}

${ }^{1}$ Lundbeck Research USA, Paramus, New Jersey, USA

${ }^{2}$ Lundbeck DK, Copenhagen-Valby, Denmark

The hippocampus plays an important role in emotional and cognitive processing, and both of these domains are affected in patients with major depressive disorder (MDD). Extensive preclinical research and the notion that modulation of serotonin (5-HT) neurotransmission plays a key role in the therapeutic efficacy of selective serotonin reuptake inhibitors (SSRIs) support the view that 5-HT is important for hippocampal function in normal and diseaselike conditions. The hippocampus is densely innervated by serotonergic fibers, and the majority of 5-HT receptor subtypes are expressed there. Furthermore, hippocampal cells often co-express multiple 5-HT receptor subtypes that can have either complementary or opposing effects on cell function, adding to the complexity of 5-HT neurotransmission. Here we review the current knowledge of how 5-HT, through its various receptor subtypes, modulates hippocampal output and the activity of hippocampal pyramidal cells in rodents. In addition, we discuss the relevance of 5-HT modulation for cognitive processing in rodents and possible clinical implications of these results in patients with MDD. Finally, we review the data on how SSRIs and vortioxetine, an antidepressant with multimodal activity, affect hippocampal function, including cognitive processing, from both a preclinical and clinical perspective.

Received 6 March 2015; Accepted 3 June 2015; First published online 8 September 2015

Key words: Hippocampus, pyramidal cell, serotonin, SSRI, vortioxetine.

\section{Clinical Implications}

- The hippocampus is involved in the regulation of emotional and cognitive processing, both of which are compromised in patients with major depressive disorder (MDD).

- Serotonin (5-HT) plays an important role in hippocampal function.

- Multiple 5-HT receptors are often co-expressed on the same cell types in the hippocampus with functions that can either be complementary or opposing. Overall, 5-HT appears to inhibit pyramidal cells in the hippocampal circuit in rodents.

* Address for correspondence: Elena Dale, PhD, Lundbeck Research USA, 215 College Rd., Paramus, NJ 07652, USA.

(Email: EDAL@lundbeck.com)

We would like to thank Dr. Bjarke Ebert (H Lundbeck A/S) and Simon Reid (Fusion Animation, London, United Kingdom) for assistance in preparing Figure 1 of the manuscript. This research was funded by Takeda Pharmaceuticals and H. Lundbeck A/S.
While selective serotonin reuptake inhibitors (SSRIs) have the potential to normalize hippocampal output under stress conditions and to treat mood symptoms in MDD, their effects on cognitive function are less clear.

- The multimodal antidepressant vortioxetine has shown clinical efficacy on mood as well as cognitive symptoms in patients with MDD. 5- $\mathrm{HT}_{3}$ receptor inhibition of GABAergic interneurons is thought to play an important role in mediating these effects.

\section{Introduction}

There is extensive evidence that depression and other stress-related conditions are associated with hippocampal dysfunction. ${ }^{1,2}$ In several magnetic resonance studies, patients with major depressive disorder (MDD) have reduced hippocampal volumes compared with matched control subjects. ${ }^{3-5}$ Furthermore, Sheline et $a l^{6}$ 
have shown that there is an inverse correlation between hippocampal volume and the duration of untreated depression. A meta-analysis of 12 clinical studies indicated that the number of depressive episodes may be correlated with a reduction of hippocampal volume in the right hemisphere. ${ }^{7}$ Reduced hippocampal volume in MDD patients has also been associated with impaired memory (eg, MacQueen $\left.e t a l^{8}\right)$. Memory function related to hippocampal integrity decreases with increasing numbers of depressive episodes. ${ }^{9}$ In addition, functional magnetic resonance imaging (fMRI) studies of depressed patients have consistently shown overactivity in the frontolimbic circuitry, including the dorsolateral prefrontal cortex and hippocampus during working memory performance. ${ }^{10,11}$

In addition to disturbances in mood and emotional processing, MDD is associated with deficits in several cognitive domains, including executive function, processing speed, and attention, as well as learning and memory. ${ }^{12-14}$ There is evidence that cognitive impairment varies independently of mood state and does not necessarily resolve when the patient is considered to be in clinical remission. ${ }^{15}$ This may imply that cognitive control and the regulation of emotion have distinct neuronal bases in depression. ${ }^{16}$ While the literature suggests that antidepressants may potentially treat cognitive dysfunction in some patients with MDD, these studies were not designed to distinguish between the direct effects on cognitive domains versus indirect effects on cognition via improvements in mood. Overall, small sample sizes, methodological constraints, and the absence of replication make it difficult to draw firm conclusions from the majority of these studies. ${ }^{17,18}$

Since the selective serotonin $(5-\mathrm{HT})$ reuptake inhibitors (SSRIs) and serotonin norepinephrine (NE) reuptake inhibitors (SNRIs) are the predominant pharmacotherapies used for the treatment of MDD, modulation of serotonergic neurotransmission is assumed to play a pivotal role in achieving their antidepressant efficacy. Many 5-HT receptor subtypes are extensively expressed in the hippocampus. However, even though a large number of preclinical studies in rodents are strongly supportive of antidepressant treatments restoring hippocampal function, their mechanisms of action have not been fully elucidated. Furthermore, it is not well understood how the clinical efficacy of currently used antidepressants might be related to changes in hippocampal function in patients with MDD. ${ }^{19}$ Therefore, a thorough understanding of how 5 -HT receptor modulation affects hippocampal functions is essential to the understanding of how antidepressants might work. Here we review the current knowledge of how 5-HT, through its various receptor subtypes, might modulate hippocampal activity in rodents. In addition, we discuss its relevance for cognitive processing and the possible clinical implications for patients with MDD. Finally, we review available data on how SSRIs and vortioxetine, an antidepressant that, in addition to inhibition of 5-HT reuptake, also modulates a number of 5-HT receptor subtypes, affect hippocampus function from a preclinical and clinical perspective.

\section{Anatomy of the Hippocampus}

To understand how 5-HT modulates hippocampal function at a molecular level, it is necessary to gain insights into how 5-HT modulates the different cell types and subregions that comprise the hippocampal microcircuits. Along the longitudinal axis, the hippocampus is segregated into dorsal, intermediate, and ventral regions in rodents (reviewed in Fanselow and Dong ${ }^{20}$ and Moser and $\operatorname{Moser}^{21}$ ), and analogous posterior and anterior regions in primates and humans ${ }^{22}$ that project to distinct brain areas. ${ }^{23}$ Lesion and electrophysiology studies in rodents have shown that the dorsal hippocampus is primarily involved in the cognitive functions, including spatial learning and memory, ${ }^{24,25}$ whereas the ventral hippocampus is primarily involved in regulating stress, emotion, and anxiety. ${ }^{26-28}$ However, this division of functions is somewhat ambiguous, since parts of the ventral hippocampus have been also shown to be involved in memory tasks. ${ }^{29}$

The hippocampus is subdivided into several distinct zones: the dentate gyrus (DG), CA3, CA2, CA1, and the subiculum regions that were first described by Ramon y Cajal in $1911^{30}$ and Lorente de Nó in $1934^{31}$ (Figure 1). The CA3, CA2, and CA1 regions are sometimes called the hippocampal gyrus or Ammon's horn. Granule cells in the DG receive projections from the surrounding entorhinal cortex and send their axons, called mossy fibers, to the CA3 area. Pyramidal cells in the CA3 area project axons, known as Schaffer collaterals, to the CA2 and CA1 areas. Pyramidal cells in the CA1 area send their axons to the surrounding deep cortical layers of the entorhinal cortex and to the subiculum which is the final processing stage of the hippocampal microcircuitry (Figure 1). In addition to this main "trisynaptic circuit," there are direct connections from the superficial layers of the entorhinal cortex to the CA3 and CA1 areas, and synaptic connections from inhibitory gamma-butyric acid (GABA)ergic interneurons to excitatory glutamatergic pyramidal and granule cells within the hippocampus. $^{32}$

There are 2 types of principal cells in the hippocampal circuit: glutamatergic pyramidal cells in the Ammon's horn and subiculum regions, and glutamatergic granule cells in the DG (Figure 1). They generally have excitatory effects on the neurons to which they send axon terminals including other glutamatergic and GABAergic, as well 

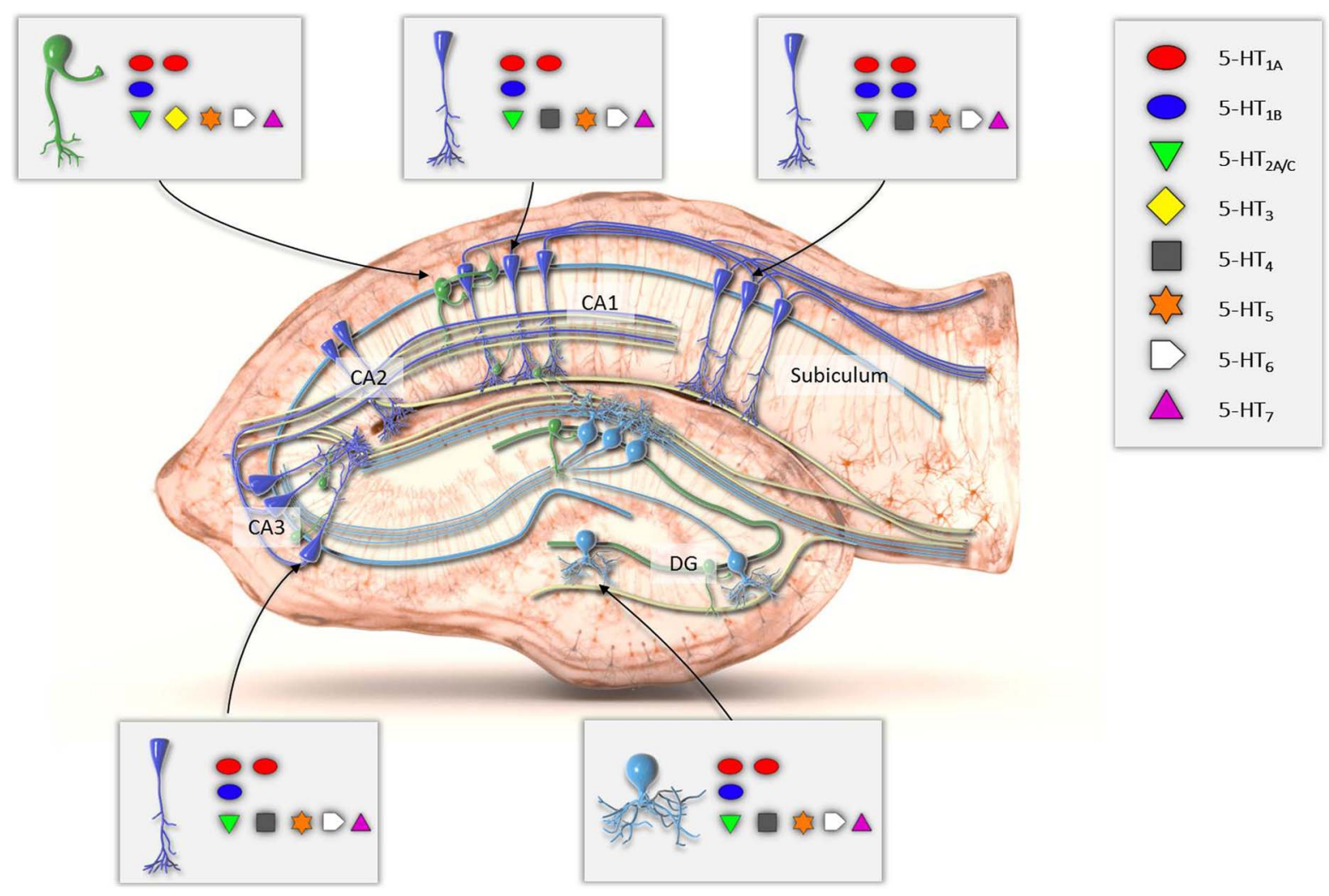

FIGURE 1. Schematic illustration of the rat hippocampal circuit with 5-HT receptor localization. The main areas of the hippocampus, including the dentate gyrus (DG), CA3, CA2, CA1, and the subiculum regions, and synaptic connections between them are indicated. Principal (granule and pyramidal) cells are shown in blue, and interneurons are shown in green. Expression of 5-HT receptor subtypes on hippocampal CA1 and CA3 pyramidal cells, granule cells, and interneurons are shown. References for $5-\mathrm{HT}$ receptor localization are listed Table 1 . At least 16 subtypes of interneurons have been identified in the hippocampus; one representative interneuron is shown for illustrative purposes. Note that the $5-\mathrm{HT}_{1 \mathrm{~A}}$ heteroreceptor is expressed at high levels throughout the hippocampus. The $5-\mathrm{HT}_{1 \mathrm{~B}}$ receptor is found at highest levels in the subiculum. Based on histology data, the $5-\mathrm{HT}_{3}$ receptor is only expressed on the interneurons, and the $5-\mathrm{HT}_{4}$ receptor is only expressed on pyramidal cells. Other 5 -HT receptors subtypes are found on both principal cells and interneurons.

monoaminergic [5-HT, norepinephrine (NE), dopamine (DA)], cholinergic, and histaminergic (HA) cells. There are also 3 major populations of GABAergic inhibitory interneurons that can be identified by the expression of the calcium-binding proteins parvalbumin, calbindin, and calretinin. These interneurons can be further subdivided based on their morphology and presence of receptors for neuropeptides and other neurotransmitters. In total at least 16 different subtypes of interneurons have been identified in the hippocampus with different firing properties and functions. ${ }^{33,34}$ Each of these interneuron subpopulations has a distinct placement within the network, as well as a distinct role in modulating the behavior of pyramidal neurons.

Parvalbumin-immunoreactive interneurons are present within the pyramidal cell body layer (divided into stratum oriens and pyramidale), and synapse onto the soma and/or axons of pyramidal neurons. ${ }^{35}$ In contrast, calbindin immunoreactive interneurons are present in the dendritic layers of the hippocampus (divided into stratum radiatum and moleculare) ${ }^{36}$ and are thought to synapse onto pyramidal neuron dendrites. ${ }^{37}$ Finally, calretinin immunoreactive interneurons frequently form local synaptic connections onto other interneurons. ${ }^{38}$ Thus, hippocampal interneurons can modulate the activity of both pyramidal cells and other interneurons. ${ }^{38}$

The processing of information within the hippocampus is complex and is influenced by multiple neurotransmitters and neuromodulators, including glutamate, GABA, DA, NE, HA, acetylcholine (ACh), and 5-HT. Serotonergic receptors are found on both excitatory cells and inhibitory interneurons. As will be discussed in the following sections, 5-HT neurotransmission can have a direct effect on pyramidal neuron firing by modulating its membrane potential and indirect effects via modulating GABA neurotransmission.

\section{5-HT Receptors in the Rodent Hippocampus}

Nearly all of the identified 5-HT receptor subtypes are expressed in the hippocampal circuit in rodents. ${ }^{39}$ Interestingly, 5-HT fibers often lack direct synaptic 
contacts, and in many cases 5 -HT receptors have been detected on neurons that do not receive serotonergic innervation. ${ }^{40-42}$ This suggests that in the hippocampus, as in other brain areas, 5-HT is released diffusely by volume transmission and acts more as a neuromodulator whose function might be to maintain homeostasis in the brain.

The specificity and diversity of 5-HT signaling arises from at least 14 different receptor subtypes grouped in 7 receptor families with distinct characteristics and expression patterns (Table 1, Figures 1 and 2). The $5-\mathrm{HT}_{1}$ receptor family is inhibitory; it is coupled to G-protein-coupled inwardly rectifying potassium (GIRK) channels and $\mathrm{G}_{\mathrm{i} / \mathrm{o}}$ proteins. Activation of GIRK channels exerts hyperpolarizing effects on cell function. Activation of $\mathrm{G}_{\mathrm{i} / \mathrm{o}}$ proteins inhibits adenylyl cyclase and decreases cyclic adenosine monophosphate (cAMP) concentration. The $5-\mathrm{HT}_{2}$ receptor family is stimulatory and signals via activation of $\mathrm{G}_{\mathrm{q}}$ proteins that are coupled to phospholipase C. Phospholipase C hydrolyses membrane phosphoinositides into inositol triphosphate (IP3) and diacylglycerol (DAG), which elevate intracellular calcium. One of the downstream targets of $5-\mathrm{HT}_{2}$ receptors are potassium leak channels. Activation of $5-\mathrm{HT}_{2}$ receptors closes these channels, resulting in cell depolarization. The $5-\mathrm{HT}_{3}$ receptor family is stimulatory and the only nonG-protein coupled receptor. Activation of $5-\mathrm{HT}_{3}$ receptors opens a non-selective $\mathrm{Na}^{+} / \mathrm{K}^{+}$ion channel that depolarizes neurons and increases neurotransmitter release. The $5-\mathrm{HT}_{4}, 5-\mathrm{HT}_{6}$, and $5-\mathrm{HT}_{7}$ receptors are stimulatory and increase neuronal excitability. They are coupled to $\mathrm{G}_{\mathrm{s}}$ protein and signal via activation of adenylyl cyclase and elevation in cAMP levels. Finally, $5-\mathrm{HT}_{5}$ receptors are inhibitory, and, as for the $5-\mathrm{HT}_{1}$ receptor family members, are coupled to $\mathrm{G}_{\mathrm{i} / \mathrm{o}}$ proteins that suppress adenylyl cyclase and decrease cAMP levels. ${ }^{43,44}$ In the hippocampus, cells often co-express several types of 5-HT receptors that can have either complementary or opposing effects on cell function (Figure 1 and Table 1). Moreover, 5-HT receptors can form homodimers or heterodimers with other G-protein coupled receptors, which adds further complexity to 5-HT signaling. ${ }^{45}$ For example, heterodimers of $5-\mathrm{HT}_{1 \mathrm{~A}}-5 \mathrm{HT}_{7}$ receptors and $5-\mathrm{HT}_{2 \mathrm{~A}}-\mathrm{mGlu} 2$ (metabotropic glutamate 2) receptors have been shown to have characteristics that differ from their individual counterparts. ${ }^{45-47}$ Below we describe the expression patterns of 5-HT receptors and discuss their effects on hippocampal circuitry and hippocampus-mediated behavioral responses based on published results and our data in rodents. We chose to only include behavioral models of memory and learning, since these models have the best link to hippocampal function. ${ }^{48-50}$

\section{5-HT ${ }_{1 A}$ receptors}

Among all 5-HT receptor subtypes, $5-\mathrm{HT}_{1 \mathrm{~A}}$ receptors have the highest affinity for 5-HT (Table 1). In the hippocampus, they are found on non-serotonergic cells as heteroreceptors and inhibit cellular activity via activating GIRK channels. ${ }^{51}$ They are defined as heteroreceptors because they control release of neurotransmitters other than 5-HT. 5-HT $1 \mathrm{~A}$ receptors are moderately to highly expressed throughout the hippocampus ${ }^{52}$ (Figure 2A). They have been detected on both glutamatergic principal cells and at least two subtypes of GABAergic interneurons (Table 1).

Activation of $5-\mathrm{HT}_{1 \mathrm{~A}}$ receptors primarily leads to inhibition of hippocampal pyramidal cells. ${ }^{53-59}$ Interestingly, in the prefrontal cortex, $5-\mathrm{HT}_{1 \mathrm{~A}}$ receptor agonists produce both excitatory and inhibitory effects on cortical

TABLE 1. 5-HT receptor subtypes in the rodent hippocampus

\begin{tabular}{|c|c|c|c|c|c|c|}
\hline Receptor & Structure & Affinity for $5-\mathrm{HT}(\mathrm{Ki} / \mathrm{Kd}, \mathrm{nM})^{*}$ & Function & Expression & Cell type & Ref. \\
\hline $5-\mathrm{HT}_{1 \mathrm{~A}}$ & GPCR & $0.20-0.79$ & I $\downarrow$ CAMP, $\uparrow$ GIRK & $++/+++$ & Pyr, Gran, Calbin-(+) IN, PV-(+) IN & 37,52 \\
\hline $5-\mathrm{HT}_{1 \mathrm{~B}}$ & GPCR & $4.0-32$ & I $\downarrow$ CAMP, $\uparrow$ GIRK & $+1+++$ & Pyr, Gran & $63,65,155$ \\
\hline $5-\mathrm{HT}_{1 \mathrm{D}}$ & GPCR & $2.5-6.3$ & I $\downarrow$ CAMP, $\uparrow$ GIRK & $-1+$ & $?$ & 64,66 \\
\hline $5-\mathrm{HT}_{2 \mathrm{~A}}$ & GPCR & 1.3 & $S \uparrow P L C$ & $+/+++$ & $\begin{array}{l}\text { Pyr, Gran, Calbin-(+) IN, Calre-(+) } \\
\quad \text { IN, PV-(+) IN }\end{array}$ & 71,72 \\
\hline $5-\mathrm{HT}_{2 \mathrm{C}}$ & GPCR & $2.5-160$ & $S \uparrow P L C$ & $?$ & $?$ & 163 \\
\hline $5-\mathrm{HT}_{3}$ & $\begin{array}{l}\text { Ligand-gated ion } \\
\text { channel }\end{array}$ & $130-320$ & $\begin{array}{l}\mathrm{S} \uparrow \text { Ion conductance } \\
\qquad\left(\mathrm{K}^{+}, \mathrm{Na}^{+}\right)\end{array}$ & $\begin{array}{l}+/++ \text { Stronger in ventral/ } \\
\text { caudal hippocampus }\end{array}$ & $\begin{array}{l}\text { CCK- }(+) \text { IN, Calbin- }(+) \text { IN, Calre- } \\
\quad(+) \text { IN }\end{array}$ & $76,77,79$ \\
\hline $5-\mathrm{HT}_{4}$ & GPCR & $1.6-4.0$ & $\mathrm{~S} \uparrow \mathrm{CAMP}$ & $+1++$ & Pyr & $89-91$ \\
\hline $5-\mathrm{HT}_{5}$ & GPCR & $130-200 * *$ & $I \downarrow$ CAMP & $+/++$ & Pyr, Gran, IN & 95 \\
\hline $5-\mathrm{HT}_{6}$ & GPCR & 13 & $\mathrm{~S} \uparrow \mathrm{CAMP}$ & $++/+++$ & Pyr, Calbin-(+) IN, Calre-(+) IN & 97,98 \\
\hline $5-\mathrm{HT}_{7}$ & GPCR & $1.0-7.9$ & $S \uparrow C A M P$ & $+/+++$ & Pyr, IN? & 104 \\
\hline
\end{tabular}

* Affinities for 5-HT were calculated from pKi/pKd data obtained from the IUPHAR data base. For further details and references see http://www.iuphar-db.org.

** $5-\mathrm{HT}_{5 \mathrm{a}}$. Expression strength is indicated by - : absent, + : low, ++ : moderate, +++ : strong, ?: unknown.

Abbreviations used: GPCR: G-protein-coupled receptor; I: inhibitory; S: stimulatory; $\uparrow$ : increase; $\downarrow$ : decrease; Pyr: pyramidal; Gran: granule; IN: interneuron; PV: parvalbumin; CCK: cholecystokinin; Calbin: calbindin; Calre: calretinin. 

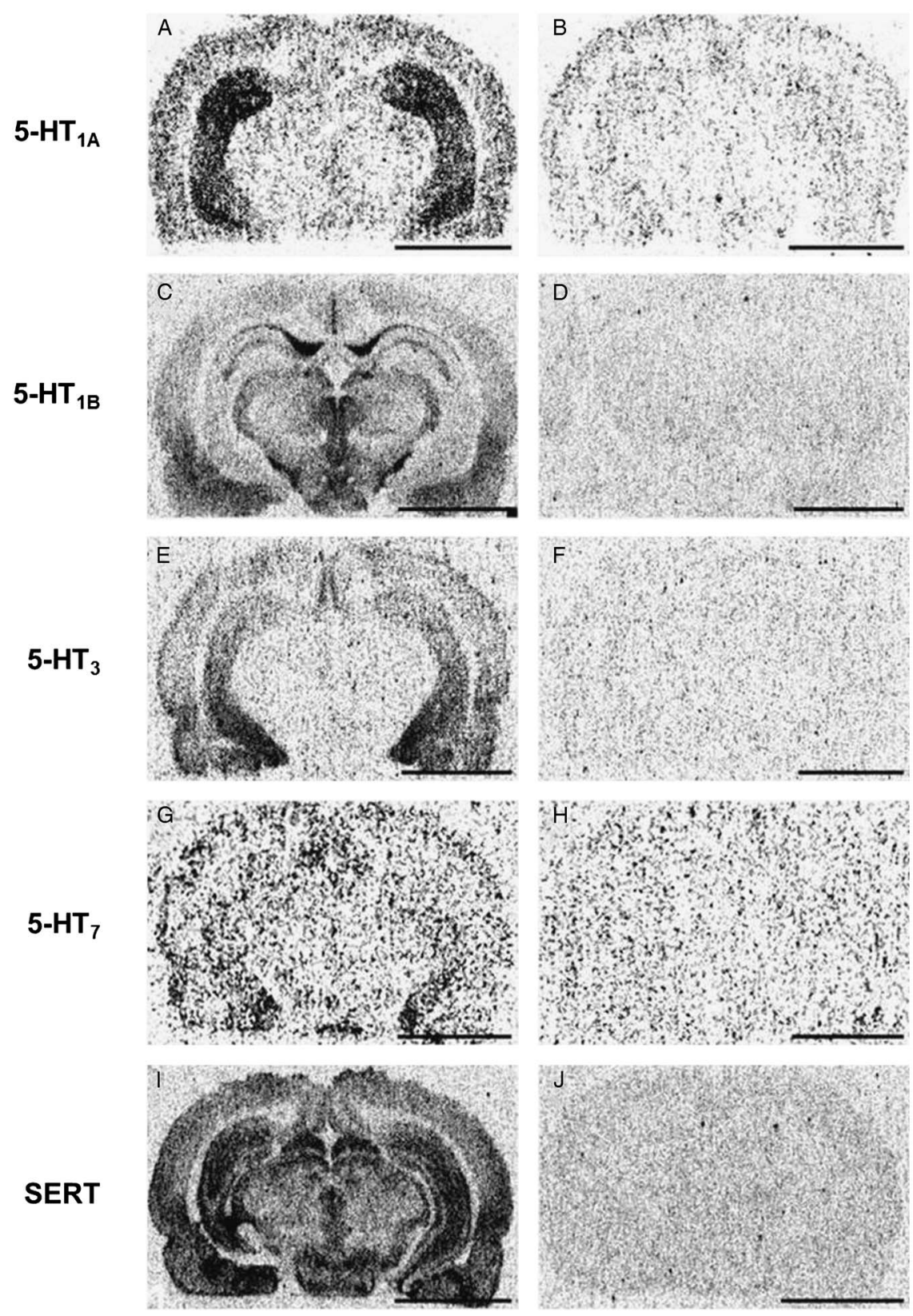

FIGURE 2. Expression of several classes of 5-HT receptors and the 5-HT reuptake transporter (SERT) by ex vivo autoradiography in the rat hippocampus. Autoradiographic images representing total (left pane/s) and non-specific binding (right pane/s) for each of 5 separate serotonergic targets in coronal brain sections (20 $\mu \mathrm{m}$ in thickness). $5-\mathrm{HT}_{1 \mathrm{~A}}$ receptors were mapped using $3 \mathrm{nM}\left[{ }^{3} \mathrm{H}\right] 8-\mathrm{OH}-\mathrm{DPAT}$ (A) alone or (B) in combination with $1 \mu \mathrm{M}$ of the $5-\mathrm{HT}_{1 \mathrm{~A}}$ receptor selective antagonist WAY100635 to determine the level of nonspecific binding. 5- $\mathrm{HT}_{1 \mathrm{~B} / 1 \mathrm{D}}$ receptors were mapped using $1 \mathrm{nM}\left[{ }^{3} \mathrm{H}\right] \mathrm{GR} 125743$ (C) alone or (D) in combination with $1 \mu \mathrm{M}$ of the $5-\mathrm{HT}_{1 \mathrm{~B}}$ receptor preferring SB216641 to determine the level of nonspecific binding. $5-\mathrm{HT}_{3}$ receptors were mapped using $3 \mathrm{nM}\left[{ }^{3} \mathrm{H}\right]$ LY278584 (E) alone or (F) in combination with $1 \mu \mathrm{M}$ ondansetron to determine the level of nonspecific binding. $5-\mathrm{HT}_{7}$ receptors were mapped using $4.5 \mathrm{nM}\left[{ }^{3} \mathrm{H}\right]$ SB269970 (G) alone or (H) in combination with $1 \mu \mathrm{M}$ of unlabeled SB269970 to determine the level of nonspecific binding. Finally, SERT was mapped using $4.5 \mathrm{nM}\left[{ }^{3} \mathrm{H}\right]$ escitalopram (I) alone or $(\mathrm{J})$ in combination with $1 \mu \mathrm{M}$ paroxetine to determine the level of nonspecific binding. Scale bars represent $5 \mathrm{~mm}$.

pyramidal cells. ${ }^{60}$ This might be ascribed to a difference in the distribution of $5-\mathrm{HT}_{1 \mathrm{~A}}$ receptors on interneurons versus pyramidal cells in these 2 brain regions.

The function of $5-\mathrm{HT}_{1 \mathrm{~A}}$ receptors has been extensively studied in multiple behavioral studies, 16 of which are listed in Table 2. Modulation of 5- $\mathrm{HT}_{1 \mathrm{~A}}$ receptor activity in animal models of memory and learning has produced inconsistent results that range from impairment to improvement (Table 2). Some of these inconsistencies might be due to differences in experimental design 
TABLE 2. Effects of serotonergic manipulations on hippocampal dependent memory tests in rodents

\begin{tabular}{|c|c|c|c|c|}
\hline Mechanism & Species & $\begin{array}{l}\text { Spatial memory tasks (Morris } \\
\text { water maze (MWM), Radial } \\
\text { arm maze (RAM), Barnes maze } \\
(\mathrm{BM}), \text { Object } \\
\text { placement/preference (OP)) }\end{array}$ & $\begin{array}{l}\text { Associative/Affective memory } \\
\text { tasks (Contextual fear } \\
\text { conditioning (CFC), Pattern } \\
\text { separation (PS)) }\end{array}$ & $\begin{array}{l}\text { Working memory tasks } \\
\text { (Spontaneous } \\
\text { alternation (SA), Forced } \\
\text { alternation (FA), } \\
\text { Delayed alternation (DA)) }\end{array}$ \\
\hline \multicolumn{5}{|l|}{$\uparrow 5$-HT tone } \\
\hline $\begin{array}{l}\text { Increase tryptophan or other 5-HT } \\
\text { precursor }\end{array}$ & Rat & $\begin{array}{l}\uparrow^{164,165} \text { or } \div{ }^{165} \mathrm{MWM} ; \uparrow^{122} \text { or } \\
\downarrow^{166} \mathrm{RAM}\end{array}$ & $\downarrow \mathrm{CFC}^{167}$ & \\
\hline $\begin{array}{l}5-\mathrm{HTT} \text { KO } \\
\text { SSR/S }\end{array}$ & \multicolumn{3}{|c|}{ SSRIS } & \\
\hline $\begin{array}{l}\text { Fluoxetine, paroxetine, citalopram, } \\
\text { escitalopram }\end{array}$ & Mouse or Rat & $\begin{array}{l}\downarrow^{171-173} \text { or } \div{ }^{174-176} \text { MWM; } \\
\quad \uparrow \mathrm{BM}^{177} ; \div \text { RAM }{ }^{178,179} ; \\
\quad \downarrow \mathrm{OP}{ }^{171,172}\end{array}$ & $\begin{array}{l}\downarrow \text { or } \div \text { CFC }{ }^{167} \text { when administrated } \\
\text { before the testing session; } \uparrow \\
\text { CFC }{ }^{180} \text { when administrated } \\
\text { before training }\end{array}$ & $\begin{array}{l}\downarrow \mathrm{FA}^{181} ; \div \text { pCPA deficit in } \\
\quad \mathrm{SA}^{182}\end{array}$ \\
\hline \multicolumn{5}{|l|}{ Multimodal } \\
\hline $\begin{array}{l}\text { Vortioxetine } \\
\downarrow 5 \text {-HT tone }\end{array}$ & Rat & & $\uparrow \mathrm{CFC}^{183}$ & $\emptyset \mathrm{pCPA}$ deficit in $\mathrm{SA}{ }^{182,184}$ \\
\hline 5,7-DHT & Rat & $\div \quad{ }^{185-190-190}$ or $\downarrow$ 191,192 MWM; $\div$ RAM & & $\begin{array}{l}\div{ }^{185,188} \text { or } \downarrow^{187} \mathrm{FA} ; \\
\quad \div S A^{186} ; \downarrow \downarrow D A{ }^{185}\end{array}$ \\
\hline $\mathrm{pCPA}$ & Rat & $\div$ MWM $^{193} ; \div$ RAM ${ }^{194}$ & & $\downarrow S A^{182}$ \\
\hline Tryptophan depletion & Mouse or Rat & $\div$ MWM $^{195,196}$ & $\downarrow$ CFC 196 & \\
\hline $\begin{array}{l}\text { Conditional KO Lmx1b } \\
\text { transcription factor lack all } \\
\text { central 5-HT neurons }\end{array}$ & Mouse & $\downarrow$ MWM 197 & $\uparrow \mathrm{CFC}^{197}$ & \\
\hline \multicolumn{5}{|l|}{$5-\mathrm{HT}_{1 \mathrm{~A}}$ receptors } \\
\hline 5-HT $\mathrm{T}_{1 \mathrm{~A}}$ Over-expression & Mouse & $\downarrow^{198}$ or $\div{ }^{199}$ MWM & & \\
\hline $5-\mathrm{HT}_{1 \mathrm{~A}} \mathrm{KO}$ & Mouse & $\begin{array}{l}\downarrow \text { in young mice; } \div \text { in old mice in } \\
\text { MWM } 200\end{array}$ & $\uparrow \mathrm{CFC}^{201} ; \downarrow \mathrm{PS}^{201}$ & \\
\hline \multicolumn{5}{|l|}{$5-\mathrm{HT}_{1 \mathrm{~A}}$ receptor agonists } \\
\hline $\begin{array}{l}\text { 8-OH-DPAT (also activates 5-HT } \\
\text { receptors); S15535; flesinoxan }\end{array}$ & Mouse or Rat & $\begin{array}{l}\uparrow^{61} ; \div \div{ }^{202} \text { or } \downarrow^{61} \mathrm{MWM} ; \downarrow^{203-206} \\
\quad \text { or } \div{ }^{207} \text { RAM }\end{array}$ & $\downarrow$ CFC 208,209 & $\emptyset \mathrm{pCPA}$ deficit in SA ${ }^{184}$ \\
\hline \multicolumn{5}{|l|}{$5-\mathrm{HT}_{1 \mathrm{~A}}$ receptor antagonists } \\
\hline $\begin{array}{l}\text { WAY } 100635 \text {, WAY } 100135 \\
\text { WAY } 101405 \text {, NAN-190, } \\
\text { NAD- } 299\end{array}$ & Mouse or Rat & $\uparrow$ MWM $^{210} ; \div$ RAM $^{204}$ & $\uparrow^{209}$ or $\div{ }^{167} \mathrm{CFC}$ & \\
\hline \multicolumn{5}{|l|}{ 5-HT ${ }_{1 \mathrm{~B}}$ receptors } \\
\hline $\begin{array}{l}5-\mathrm{HT}_{1 \mathrm{~B}} \text { over-expression (in dorsal } \\
\text { raphe nucleus) }\end{array}$ & Rat & & $\downarrow \mathrm{CFC}^{211}$ & \\
\hline $\begin{array}{l}5-\mathrm{HT}_{1 \mathrm{~B}} \mathrm{KO} \\
5-\mathrm{HT}_{1 \mathrm{~B}} \text { receptor agonists }\end{array}$ & Mouse & $\uparrow M W M^{212,213}$ & $\div \mathrm{CFC}^{213}$ & $\div S A^{213}$ \\
\hline CP93129, Anpirtoline & Rat & $\downarrow$ MWM $^{214} ; \downarrow \downarrow$ RAM $^{207}$ & $\downarrow \mathrm{CFC}^{211}$ & \\
\hline \multicolumn{5}{|l|}{$5-\mathrm{HT}_{1 \mathrm{~B}}$ receptor antagonists } \\
\hline GR127935 $\left(5-\mathrm{HT}_{1 \mathrm{~B} / 1 \mathrm{D}}\right), \mathrm{NAS}-181$ & Rat & $\div M^{\prime} M^{214}$ & $\div \mathrm{CFC}^{167}$ & \\
\hline $\begin{array}{l}\text { 5- } \mathrm{HT}_{2} \text { receptor agonists } \\
\text { DOI, mCPP }\end{array}$ & Rat & $\uparrow \mathrm{MWM}^{215} ; \downarrow$ RAM, ${ }^{166}$ & & \\
\hline \multicolumn{5}{|l|}{$5-\mathrm{HT}_{2}$ receptor antagonists } \\
\hline Ritanserin, ketanserin, ICl169369 & Rat & $\uparrow^{216}$ or $\downarrow^{215} \mathrm{MWM}^{2} \div$ RAM $^{217}$ & $\div \mathrm{CFC}^{167}$ & \\
\hline \multicolumn{5}{|l|}{$5-\mathrm{HT}_{2 \mathrm{~A}}$ receptor } \\
\hline 5- $\mathrm{HT}_{2 \mathrm{~A}}$ antisense & Rat & $\uparrow M_{W M}{ }^{218}$ & & \\
\hline $5-\mathrm{HT}_{2 \mathrm{~A}} \mathrm{KO}$ & Mouse & & $\div \mathrm{CFC}^{208}$ & \\
\hline \multicolumn{5}{|l|}{$5-\mathrm{HT}_{2 \mathrm{~A}}$ receptor agonist } \\
\hline TCB-2 & Mouse & & $\begin{array}{l}\uparrow \mathrm{CFC}^{219} \text { (both consolidation and } \\
\text { extinction) }\end{array}$ & \\
\hline \multicolumn{5}{|l|}{$5-\mathrm{HT}_{2 \mathrm{~A}}$ receptor antagonist } \\
\hline MDL 11,939 & Mouse & & $\downarrow \mathrm{CFC}^{219}$ (extinction) & \\
\hline \multicolumn{5}{|l|}{ 5-HT $2 \mathrm{C}$ receptor } \\
\hline 5- $\mathrm{HT}_{2 \mathrm{C}}$ null mutant & $5-\mathrm{HT}_{2 \mathrm{c}}$ receptor antagonist & $\downarrow M^{2} M^{220}$ & $\downarrow \mathrm{CFC}^{220} ; \div$ PS ${ }^{220}$ & \\
\hline SB242084 & Rat & & $\div \mathrm{CFC}^{221}$ & \\
\hline \multicolumn{5}{|l|}{$5-\mathrm{HT}_{3}$ receptor } \\
\hline $5-\mathrm{HT}_{3}$ over expression & Mouse & & $\uparrow \mathrm{CFC}^{224}$ & \\
\hline $5-\mathrm{HT}_{3 \mathrm{~A}} \mathrm{KO}$ & Mouse & & $\div$ CFC $^{208}$ & \\
\hline
\end{tabular}


TABLE 2: Continued

\begin{tabular}{|c|c|c|c|c|}
\hline Mechanism & Species & $\begin{array}{l}\text { Spatial memory tasks (Morris } \\
\text { water maze (MWM), Radial } \\
\text { arm maze (RAM), Barnes maze } \\
\text { (BM), Object } \\
\text { placement/preference (OP)) }\end{array}$ & $\begin{array}{l}\text { Associative/Affective memory } \\
\text { tasks (Contextual fear } \\
\text { conditioning (CFC), Pattern } \\
\text { separation (PS)) }\end{array}$ & $\begin{array}{l}\text { Working memory tasks } \\
\text { (Spontaneous } \\
\text { alternation (SA), Forced } \\
\text { alternation (FA), } \\
\text { Delayed alternation (DA)) }\end{array}$ \\
\hline \multicolumn{5}{|l|}{$5-\mathrm{HT}_{3}$ receptor antagonists } \\
\hline $\begin{array}{l}\text { WAY } 100289 \text {, granisetron, } \\
\text { tropisetron, ondansetron, } \\
\text { DAU6215 }\end{array}$ & Mouse or Rat & $\downarrow^{216}$ or $\div{ }^{222,223}$ MWM; $\uparrow$ RAM $^{88}$ & $\downarrow^{167,208,224}$ or $\div^{221}$ in CFC & $\div$ pCPA deficit in SA ${ }^{184}$ \\
\hline \multicolumn{5}{|l|}{$5-\mathrm{HT}_{4}$ receptor } \\
\hline $5-\mathrm{HT}_{4} \mathrm{KO}$ & Mouse & $\div$ MWM $^{225}$ & & \\
\hline \multicolumn{5}{|l|}{$5-\mathrm{HT}_{4}$ receptor agonist } \\
\hline prucalopride, RS 67333 & Rat & $\div M_{W W}{ }^{226}$ & & $\uparrow F A^{227}$ \\
\hline \multicolumn{5}{|l|}{$5-\mathrm{HT}_{4}$ receptor antagonist } \\
\hline RS 67532 & Rat & $\div$ MWM $^{228}$ & & \\
\hline \multicolumn{5}{|l|}{$5-\mathrm{HT}_{6}$ receptor } \\
\hline Antisense oligonucleotide & Rat & $\uparrow$ MWM $^{229}$ & & \\
\hline \multicolumn{5}{|l|}{$5-\mathrm{HT}_{6}$ receptor antagonists } \\
\hline SB271046, SB357134, Ro046790 & Mouse or Rat & $\uparrow^{229-231}, \div$ or $\downarrow^{232} \mathrm{MWM}$ & & \\
\hline \multicolumn{5}{|l|}{$5-\mathrm{HT}_{7}$ receptor } \\
\hline KO & Mouse & $\div \mathrm{BM}^{233} ; \downarrow \mathrm{OP}^{233}$ & $\downarrow \mathrm{CFC}^{233}$ & \\
\hline \multicolumn{5}{|l|}{$5-\mathrm{HT}_{7}$ receptor antagonists } \\
\hline SB656104A, SB269970 & Mouse or Rat & $\uparrow \mathrm{RAM}^{233,234} \downarrow \mathrm{OP}^{233}$ & & \\
\hline
\end{tabular}

$\div$ : no effect; $\uparrow$ : increase/improve; $\downarrow$ : decrease/impair; $\emptyset$ : prevented/reduced deficits. Abbreviations used: MWM: Morris Water Maze; RAM: Radial Arm Maze; BM: Barnes Maze; OP: Object Placement (Preference); CFC: Contextual Fear Conditioning; PS: Pattern Separation; SA: Spontaneous Alternation; FA: Forced Alternation; DA: Delayed Alternation.

across studies. Multiple factors, such as drug dose, length of treatment (acute vs chronic), whether the drug was administered before or after the training period, and also the age and stain of animals, could all influence the behavioral outcome. However, in some studies (eg, Haider et $a l^{61}$ ), opposing results were obtained with different doses of the same compound under the same experimental conditions. This suggests that the variability in results might be partially due to the complex effects of $5-\mathrm{HT}_{1 \mathrm{~A}}$ receptors expressed on different cell types. For instance, $5-\mathrm{HT}_{1 \mathrm{~A}}$ receptors can inhibit both principal (glutamatergic) neurons and GABAergic interneurons. Inhibition of GABAergic interneurons would disinhibit principal cells and thus counteract the direct effects of $5-\mathrm{HT}_{1 \mathrm{~A}}$ receptors expressed on principal neurons. Therefore, selectively targeting $5-\mathrm{HT}_{1 \mathrm{~A}}$ receptors may not be an optimal strategy for modulating hippocampal function, unless these receptors could be targeted in a regional or cell-specific manner. ${ }^{62}$

\section{5-HT $1 B$ and $5-H T_{1 D}$ receptors}

$5-\mathrm{HT}_{1 \mathrm{~B}}$ heteroreceptors are found throughout the hippocampus at levels ranging from low to very high. ${ }^{63-65}$ They are expressed on axonal terminals and dendrites of principal cells, which include pyramidal cells in Ammon's horn and granule cells in the DG (Table 1). The highest expression is found in the dorsal subiculum, which might originate from axonal terminals of CA1 pyramidal cells that project to that region (Figure 2C). ${ }^{65}$ Interestingly, in our experiments, the subiculum had the strongest signal for $5-\mathrm{HT}_{1 \mathrm{~B}}$ receptor expression in the rodent forebrain.

Much less is known about the $5-\mathrm{HT}_{1 \mathrm{D}}$ receptor. $5-\mathrm{HT}_{1 \mathrm{D}}$ receptors are generally thought to be expressed at much lower levels than $5-\mathrm{HT}_{1 \mathrm{~B}}$ receptors in the rodent brain. ${ }^{64,66} 5-\mathrm{HT}_{1 \mathrm{D}}$ and $5-\mathrm{HT}_{1 \mathrm{~B}}$ receptors are often expressed in the same brain regions. ${ }^{64}$ However, no $5-\mathrm{HT}_{1 \mathrm{D}}$ receptor-specific binding has been detected in the dorsal subiculum, where $5-\mathrm{HT}_{1 \mathrm{~B}}$ receptor-specific binding is very strong. ${ }^{66}$ Interestingly, Xie et $_{a l}{ }^{67}$ suggest that when $5-\mathrm{HT}_{1 \mathrm{~B}}$ and $5-\mathrm{HT}_{1 \mathrm{D}}$ receptors are co-expressed, they might exist in a heterodimerized state. Thus, it can be questioned if the effects of $5-\mathrm{HT}_{1 \mathrm{~B}}$ and $5-\mathrm{HT}_{1 \mathrm{D}}$ receptors should be considered separately.

Activation of $5-\mathrm{HT}_{1 \mathrm{~B}}$ receptors attenuates glutamate transmission in the subiculum and CA1 regions of the hippocampus. ${ }^{68,69}$ The effect of $5-\mathrm{HT}_{1 \mathrm{~B}}$ receptor modulation in behavioral models of memory and learning has been far less studied than that for $5-\mathrm{HT}_{1 \mathrm{~A}}$ receptors (Table 2). In general, several studies suggest that $5-\mathrm{HT}_{1 \mathrm{~B}}$ receptor stimulation may negatively affect performance in hippocampal-dependent memory tests. Antagonism of $5-\mathrm{HT}_{1 \mathrm{~B}}$ receptors, in spite of its associated increase in extracellular ACh levels in the dorsal hippocampus, ${ }^{70}$ does not seem be effective in these models (Table 2 ). 


\section{5-HT $T_{2 A}$ and $5-H T_{2 C}$ receptors}

$5-\mathrm{HT}_{2 \mathrm{~A}}$ receptors are broadly present within the hippocampus, but little is known about the expression of $5-\mathrm{HT}_{2 \mathrm{C}}$ receptors. ${ }^{71,72} 5-\mathrm{HT}_{2 \mathrm{~A}}$ receptors are expressed on both principal glutamatergic cells (on their somatic and dendritic regions) and on all known subtypes of hippocampal interneurons (Table 1). There is also some evidence suggesting that $5-\mathrm{HT}_{2 \mathrm{~A}}$ receptors are expressed on mossy fibers in the CA3 region. ${ }^{71,73}$ Thus, since $5-\mathrm{HT}_{2 \mathrm{~A}}$ receptors are stimulatory and are expressed on both principal cells and GABAergic interneurons, it would be expected that they would have mixed effects on the firing of principal cells. However, data from 2 electrophysiological studies in brain slices suggest that the effects that $5-\mathrm{HT}_{2}$ receptors have on interneurons might overwhelm their direct excitatory effects on principal cells. ${ }^{74,75}$ Further research is needed to confirm these observations and clarify which of the 2 effects of $5-\mathrm{HT}_{2}$ receptors (indirect inhibition or direct excitation of principal neurons) prevails in physiological conditions.

Studies of selective $5-\mathrm{HT}_{2}$ receptor ligands in behavioral models show variable effects (Table 2), possibly reflecting differences in experimental design across studies and the fact that $5-\mathrm{HT}_{2}$ receptors are expressed on multiple cell types in the hippocampus (Table 1). Little is known about the effects of $5-\mathrm{HT}_{2 \mathrm{C}}$ receptor modulation due to a lack of selective compounds. Thus, as with the $5-\mathrm{HT}_{1 \mathrm{~A}}$ receptor, selective targeting of $5-\mathrm{HT}_{2}$ receptors may not be an optimal strategy for modulating hippocampal function due to their varying functions in this brain region.

\section{$5-\mathrm{HT}_{3}$ receptors}

$5-\mathrm{HT}_{3}$ receptors are also found throughout the hippocampus. ${ }^{76,77}$ Autoradiographic data from our laboratory suggest that $5-\mathrm{HT}_{3}$ receptors have a distinct expression gradient within the hippocampus, with the highest expression observed in the caudal and ventral portions (Figure 2E). Interestingly, histological evidence in the rodent forebrain suggests that $5-\mathrm{HT}_{3}$ receptors are almost exclusively expressed on GABAergic interneurons. ${ }^{78,79} 5-\mathrm{HT}_{3}$ receptor-expressing interneurons are generally immunopositive for cholecystokinin, and for the calcium binding proteins calretinin and calbindin. ${ }^{79}$

Based on this histological evidence, it can be hypothesized that $5-\mathrm{HT}_{3}$ receptors provide a fast excitatory drive onto hippocampal GABAergic interneurons and inhibit hippocampal principal cells. Consistent with this hypothesis, pharmacological activation of $5-\mathrm{HT}_{3}$ receptors depolarizes hippocampal interneurons $^{80,81}$ and increases inhibitory drive onto CA1 pyramidal cells. ${ }^{82-85}$ Conversely, $5-\mathrm{HT}_{3}$ receptor antagonists inhibit hippocampal interneurons, increase the firing rate of pyramidal cells, and enhance long-term potentiation (LTP) in in vivo electrophysiology recordings in rats. ${ }^{86-88}$ Taken together, these mechanistic findings might point to a pro-cognitive effect of $5-\mathrm{HT}_{3}$ receptor antagonism. However, behavioral studies of selective $5-\mathrm{HT}_{3}$ receptor antagonists in models of memory and learning have again shown inconsistent results (Table 2).

\section{5- $\mathrm{HT}_{4}$ receptors}

Autoradiographic studies have demonstrated the presence of $5-\mathrm{HT}_{4}$ receptors throughout the hippocampus. $^{89,90}$ In general, protein expression is lowto-moderate, with the highest levels found in the stratum oriens and pyramidale of Ammon's horn, subiculum, and the molecular layer of the DG (Table 1). 5- $\mathrm{HT}_{4}$ receptor mRNA has been detected in hippocampal pyramidal cells. ${ }^{91}$ Interestingly, $5-\mathrm{HT}_{4}$ receptor mRNA was not found in cells expressing glutamic acid decarboxylase 65 (GAD65), which is thought to be a selective marker of GABAergic neurons. ${ }^{91}$ Thus, it appears that $5-\mathrm{HT}_{4}$ receptors preferentially act to stimulate pyramidal neurons, without directly modulating GABA neurotransmission. In support of this hypothesis, 2 electrophysiology studies have shown that stimulation of $5-\mathrm{HT}_{4}$ receptors increases the excitability of CA1 pyramidal cells. ${ }^{92,93}$

$5-\mathrm{HT}_{4}$ receptors have been shown to modulate the cholinergic system. In microdialysis recordings, application of the $5-\mathrm{HT}_{4}$ receptor agonist SC53116 causes a release of ACh, and this effect is blocked by the $5-\mathrm{HT}_{4}$ receptor antagonist GR113808. ${ }^{94}$ Thus in theory, $5-\mathrm{HT}_{4}$ receptor agonists should be pro-cognitive. This hypothesis has been investigated in preclinical models, but the results to date have been disappointing (Table 2).

\section{5-HT ${ }_{5}$ receptors}

Immunohistochemical expression studies have shown that $5-\mathrm{HT}_{5}$ receptors are present in some portions of the hippocampus. For example, Oliver et al ${ }^{95}$ observed moderate immunoreactivity levels in CA1, CA2, and CA3 regions and weak immunoreactivity levels in the DG. This study also reported that $5-\mathrm{HT}_{5}$ receptors were present on pyramidal and granule principal cells and on interneurons in the DG. ${ }^{95}$ Due to the lack of selective compounds, no mechanistic and behavioral studies targeting $5-\mathrm{HT}_{5}$ receptors have been performed in rodents.

\section{5-HT $\mathrm{T}_{6}$ receptors}

Histochemical studies suggest that $5-\mathrm{HT}_{6}$ receptors are expressed at moderate-to-high levels in all subfields of the rodent hippocampus. ${ }^{96,97}$ The expression is particularly strong in the molecular layer of the DG and in the stratum oriens and stratum radiatum of CA1, 
where $5-\mathrm{HT}_{6}$ receptors are thought to be expressed on dendritic processes of pyramidal cells. ${ }^{97}$ Moderate levels of $5-\mathrm{HT}_{6}$ receptor immunoreactivity have been observed in CA2 and CA3 regions. There has been also one report showing the expression of $5-\mathrm{HT}_{6}$ receptors on a subset of calretinin- and calbindin-positive hippocampal interneurons. $^{98}$

Pharmacological stimulation of $5-\mathrm{HT}_{6}$ receptors by the $5-\mathrm{HT}_{6}$ receptor agonist WAY-181187 increases GABA transmission and attenuates LTP in the CA1 area of the hippocampus. ${ }^{99}$ Both of these effects were blocked by the selective $5-\mathrm{HT}_{6}$ receptor antagonists $\mathrm{SB}-399885 .^{99}$ Furthermore, systemic administration of WAY-181187 increases GABA levels in several brain regions, including the dorsal hippocampus. ${ }^{100}$ Consistent with its enhancing effect on GABA transmission, antagonism of $5-\mathrm{HT}_{6}$ receptors increases extracellular glutamate levels in the frontal cortex and dorsal hippocampus. ${ }^{101}$ However, although the potentiating effects of $5-\mathrm{HT}_{6}$ receptors on GABA transmission have been well documented, it is not clear whether these responses are due to direct effects of $5-\mathrm{HT}_{6}$ receptors on GABAergic interneurons. ${ }^{102}$

Several $5-\mathrm{HT}_{6}$ receptor antagonists are currently in clinical development for the treatment of Alzheimer's disease. ${ }^{103}$ However, in rodent hippocampus-dependent behavioral models, the effects of $5-\mathrm{HT}_{6}$ receptor antagonists have been only investigated in a small number of studies with variable results (Table 2).

\section{$5-\mathrm{HT}_{7}$ receptors}

Immunohistochemical data suggest that $5-\mathrm{HT}_{7}$ receptors are expressed throughout Ammon's horn, especially on the soma and dendrites of pyramidal neurons. ${ }^{104}$ There is also weak $5-\mathrm{HT}_{7}$ receptor expression in the DG. ${ }^{104} \mathrm{It}$ is important to note that in the rodent brain expression of $5-\mathrm{HT}_{7}$ receptors changes during development. It is the highest during the first 2 post-natal weeks and progressively decreases with age. ${ }^{105-107}$ Our autoradiographic data using the selective $5-\mathrm{HT}_{7}$ receptor antagonist $\left[{ }^{3} \mathrm{H}\right]$ SB269970 did not show strong binding in the hippocampal sections taken from adult rats (Figure 2G). This result raises questions regarding the level of expression of $5-\mathrm{HT}_{7}$ receptors in the adult rodent hippocampus.

$5-\mathrm{HT}_{7}$ receptor stimulation increases the firing of pyramidal neurons and glutamatergic transmission in hippocampal brain slices. ${ }^{108-111}$ Stimulation of $5-\mathrm{HT}_{7}$ receptors also enhances inhibitory transmission in the hippocampus. ${ }^{112}$ This suggests that $5-\mathrm{HT}_{7}$ receptors might be expressed on GABAergic interneurons; however, there are no histological data available to support this notion. In behavioral studies, both $5-\mathrm{HT}_{7}$ agonists and antagonists have shown both memory-enhancing and memory-impairing properties depending on the animal model and test conditions (such as 5-HT tone)
(Table 2). ${ }^{113,114}$ Thus, additional research is needed to determine the role of $5-\mathrm{HT}_{7}$ receptors on cognition and memory function.

\section{Effect of 5-HT and SSRIs on CA1 Pyramidal Cells and Hippocampal Function}

Given that most 5-HT receptors are expressed on both excitatory cells and inhibitory interneurons and can function in either a stimulatory or inhibitory manner depending on the receptor subtype, it would be expected that the net effect of 5-HT on hippocampal function depends on local 5-HT concentration, the ratio of different 5-HT receptor subtypes expressed, and the density of 5-HT receptors in a particular population of cells. In general, 5-HT inhibits CA1 pyramidal cells and thereby decreases hippocampal output in rodents (reviewed by Ciranna ${ }^{108}$ ). Stimulation of the serotonergic projection from the dorsal raphe nucleus to the hippocampus decreases the firing rate of CA1 pyramidal cells in anesthetized animals. ${ }^{55,115-118}$ In a similar manner, application of 5-HT to hippocampal brain slices inhibits the function of pyramidal neurons by hyperpolarizing their membrane potential and increasing local GABA transmission. ${ }^{53,74,83-85}$ There have also been reports of excitatory effects of 5-HT on pyramidal cell function, but the magnitude of excitation was much smaller than the 5-HT-induced inhibition. ${ }^{53,119}$ However, one has to be careful in interpreting the ex vivo results obtained in brain slices; in most of these studies, 5-HT was exogenously applied at moderately high concentrations (15-50 micromolar), which might be higher than physiologically relevant concentrations of 5-HT in the brain. Therefore, these studies might exaggerate a contribution of certain subtypes of 5-HT receptors to its overall response. In summary, it seems that the overall effect of 5-HT on the hippocampal circuit in rodents is to inhibit pyramidal cell output. However, a majority of the studies that have led to this conclusion were either done in anesthetized animals or in brain slice preparations, and conclusions from such studies should be therefore interpreted with caution.

The inhibitory effect of 5-HT in the hippocampus is mediated via its actions on $5-\mathrm{HT}_{1 \mathrm{~A}}, 5-\mathrm{HT}_{1 \mathrm{~B}}, 5-\mathrm{HT}_{2 \mathrm{~A}}$ / $5-\mathrm{HT}_{2 \mathrm{C}}, 5-\mathrm{HT}_{3}, 5-\mathrm{HT}_{6}$, and possibly $5-\mathrm{HT}_{7}$ receptors. ${ }^{53-55,74,81-84,99,112,120}$ Activation of $5-\mathrm{HT}_{1 \mathrm{~A}}$ receptors has a direct inhibitory effect on pyramidal cell firing by hyperpolarizing their membrane potential via activating a potassium conductance. ${ }^{53-55}$ Other 5-HT receptors subtypes decrease the activity of pyramidal cells indirectly by mainly activating interneurons and enhancing GABA transmission onto pyramidal cells. ${ }^{7,81-84,99,112,120}$ Multiple synaptic connections from hippocampal interneurons onto pyramidal cells might further amplify the inhibitory effect of 5-HT in the hippocampus. ${ }^{102}$ 
SSRIs, which act through the inhibition of the 5-HT transporter, are among the most studied serotonergic agents. Microdialysis studies in rodents have shown that systemic administration of SSRIs rapidly enhances extracellular 5-HT concentrations in multiple brain regions, including the ventral hippocampus. ${ }^{121-123}$ Although SSRIs are selective for the serotonergic system, they do not show selectivity for 5-HT receptor subtypes and could, in theory, simultaneously activate all 5-HT receptors. However, since 5-HT receptors have different affinities for $5-\mathrm{HT}$, with $5-\mathrm{HT}_{1 \mathrm{~A}}$ receptors being the most sensitive type (Table 1), local 5 -HT concentrations in the brain would determine which 5-HT receptor subtypes become engaged upon SSRI treatment. In addition, chronic treatment with SSRIs, which is often required to achieve clinical efficacy, can desensitize and change expression patterns of 5 -HT receptor subtypes. ${ }^{124}$ For instance, chronic treatment with paroxetine desensitizes presynaptic $5-\mathrm{HT}_{1 \mathrm{~A}}$ autoreceptors in the raphe nuclei, which leads to increased serotonergic transmission. ${ }^{125,126}$

In electrophysiology studies, the effect of SSRIs in the hippocampus has been mostly studied in relationship to hippocampal LTP, which is thought to be important for learning and memory. ${ }^{127}$ In a majority of studies in normal animals, both the application of 5-HT and acute and chronic treatments with SSRIs inhibit hippocampal LTP. ${ }^{87,128-132}$ Interestingly, exposure to stress also impairs LTP in the CA1 and DG regions of the hippocampus (reviewed by Pittenger et $a l^{133}$ and Popoli et $a l^{134}$ ). Chronic treatments with SSRIs can reverse these stress-induced deficits in LTP, ${ }^{135,136}$ which suggests that SSRIs can restore hippocampal function in disease-like conditions. The positive effects of SSRIs are thought to be mediated, at least in part, by increasing the expression of brain-derived neurotrophic factor (BDNF) and neurogenesis in the hippocampal and cortical circuits. ${ }^{23,133}$

Consistent with the hypothesis that SSRIs might stimulate multiple hippocampal 5-HT receptors expressed on different cell types, their net effects in behavioral cognition models have been limited and variable. The clinical experience with SSRIs is aligned with the preclinical data. Thus, while fMRI studies reveal that the neural systems important for emotional processing are adequately normalized by SSRIs in the treatment of depression, ${ }^{137}$ SSRIs are unable to correct the over-activation of the frontolimbic circuitry important for the non-emotional cognition. ${ }^{11}$ Although there are studies showing that SSRIs can remediate "hippocampal-related" cognitive deficits in patients with depression, ${ }^{19}$ a recent study by Herzallah et $a l^{138}$ indicates that SSRIs can also impair hippocampusdependent generalization of past learning to novel contexts.

In conclusion, the regulation of hippocampal function by 5 -HT is complex, involving multiple receptor subtypes and diverse expression patterns of 5-HT receptors on principal glutamatergic cells and GABAergic interneurons. Thus, administration of an SSRI may not be a rational approach to achieve enhanced hippocampal output and subsequent improvement of cognitive function in patients with MDD due to the potential of activation of multiple receptor subtypes, which may have opposing effects on cell function. On the other hand, targeting a single 5-HT receptor subtype may not be a viable strategy either due to redundancies in the serotonergic system. The consequences of modulating one 5 -HT receptor may be attenuated by effects through other 5-HT receptor subtypes. Drugs designed to target single 5-HT receptors have so far not yielded new pharmacological treatments. For example, the selective $5-\mathrm{HT}_{1 \mathrm{~A}}$ receptor agonist flesinoxan was under development for the treatment of generalized anxiety disorder for many years, but its clinical program was stopped in the late 1990s after it failed to show efficacy in 2 large phase-3 clinical trials. ${ }^{139}$ The $5-\mathrm{HT}_{1 \mathrm{~B} / 1 \mathrm{D}}$ receptor antagonist elzasonan (CP-448187) was recently under development for the treatment of MDD and was tested in several phase-2 clinical trials, but its development program was also discontinued. ${ }^{140}$ An alternative approach to targeting a single receptor subtype could be to target a combination of 5-HT receptor subtypes that would work in a concerted manner. The multimodal antidepressant vortioxetine is an example of such an approach.

\section{Effects of the Multimodal Antidepressant Vortioxetine on Hippocampus Function}

Vortioxetine is a $5-\mathrm{HT}_{3}, 5-\mathrm{HT}_{7}$, and $5-\mathrm{HT}_{1 \mathrm{D}}$ receptor antagonist, a $5-\mathrm{HT}_{1 \mathrm{~B}}$ receptor partial agonist, a $5-\mathrm{HT}_{1 \mathrm{~A}}$ receptor agonist, and a SERT inhibitor in cellular assays. ${ }^{141,142}$ Vortioxetine has been approved for the treatment of MDD in the US, the EU, Australia and several other countries. Furthermore, clinical studies with cognitive outcome measures have shown that vortioxetine significantly improves cognitive function in MDD patients compared with placebo treatment. The efficacy of vortioxetine on cognitive function has been demonstrated in 3 randomized, double-blinded, placebocontrolled studies in MDD patients. ${ }^{143-145}$ One clinical trial was conducted in elderly MDD patients with cognition as a secondary pre-defined outcome and included 128 patients in the placebo group, 136 patients in the vortioxetine-treated group, and 128 patients in the duloxetine-treated group. ${ }^{143}$ The other 2 clinical trials were designed to compare the efficacy of vortioxetine to that of placebo on cognitive function as the primary efficacy outcome and on depressive symptoms as the secondary efficacy outcome. ${ }^{144,145}$ The study by McIntyre et $a l^{144}$ included 196 patients in the placebo group, 195 patients in the $10 \mathrm{mg}$ vortioxetine group, and 207 patients in the $20 \mathrm{mg}$ vortioxetine group. The study 
by Mahableshwarkar et al ${ }^{145}$ had 194 patients in the placebo group, 198 patients in the vortioxetine-treated group, and 210 patients in the duloxetine-treated group. These clinical studies demonstrated that vortioxetine improves objective measures of processing speed, executive function, attention and learning, and memory, including hippocampus-dependent memory measures. ${ }^{143,144,145}$ Path analyses suggested that the effect on cognitive function was largely independent of its effect on improvements in mood symptoms, supporting the hypothesis that these domains do not necessarily track together. Furthermore, an fMRI study showed that vortioxetine reduced neural activity in the left hippocampus during a working memory task in patients remitted from depression. ${ }^{146}$ This indicates that vortioxetine, unlike SSRIs, might restore compensatory overactivation in the hippocampus by increasing neural efficiency. ${ }^{11}$

Consistent with clinical findings, vortioxetine has shown antidepressant as well as pro-cognitive activities in a number of preclinical animal models. ${ }^{147}$ Furthermore, in several behavioral and mechanistic studies that engaged hippocampal and cortical circuitry, vortioxetine's effects differentiated from those of SSRIs and SNRIs. ${ }^{147}$ In the following paragraphs, we review these preclinical results and discuss how vortioxetine might modulate hippocampal function and affect hippocampus-dependent cognitive behaviors in rodents.

Acute and chronic treatments with vortioxetine increase extracellular 5-HT levels in the rat ventral hippocampus to a much greater extent than those observed with SSRIs. ${ }^{148,149}$ Interestingly, combining an SSRI with the $5-\mathrm{HT}_{3}$ receptor antagonist ondansetron resulted in a similar potentiating effect on 5-HT levels. ${ }^{148}$ This suggests that the effect of vortioxetine was at least partially due to its $5-\mathrm{HT}_{3}$ receptor antagonism. Since $5-\mathrm{HT}_{3}$ receptors are expressed on GABAergic neurons, ${ }^{76,150}$ it was hypothesized that vortioxetine, through its blockade of $5-\mathrm{HT}_{3}$ receptors, reduces GABA release and thereby attenuates the inhibitory effect that GABA exerts on 5 -HT release in the hippocampus. ${ }^{151}$ Recent data by Riga et $a l^{151}$ support this hypothesis. In their study, local application of ondansetron to the ventral hippocampus augmented the effect of the SSRI escitalopram on increasing extracellular 5-HT levels. This effect was reversed by the local application of the $\mathrm{GABA}_{\mathrm{B}}$ receptor agonist baclofen, which restored $\mathrm{GABA}_{\mathrm{B}}$ receptor tone in the hippocampus. ${ }^{151}$ Locally applied baclofen also attenuated the potentiating effect of vortioxetine on extracellular 5-HT. Taken together, these results indicate that $5-\mathrm{HT}_{3}$ receptor antagonism plays a prominent role in the vortioxetine's effect on 5-HT levels in the hippocampus.

Although $5-\mathrm{HT}_{3}$ receptor antagonism is important in the pharmacology of vortioxetine, contributions from its other receptor activities cannot be ruled out. For instance, an in vivo electrophysiology study of pyramidal neurons in the CA3 area of the hippocampus by El Mansari et $a l^{152}$ showed that vortioxetine acts as a partial agonist of $5-\mathrm{HT}_{1 \mathrm{~B}}$ receptors and can function as either an agonist or an antagonist depending on the endogenous 5-HT tone. Vortioxetine enhanced the inhibitory effect of the stimulation of the 5-HT bundle at a high, but not at a low frequency, and reversed the inhibitory effect of the $5-\mathrm{HT}_{1 \mathrm{~B}}$ receptor agonist CP 94253. ${ }^{152}$ Thus, vortioxetine also modulates the intra-hippocampal circuitry through its effects at $5-\mathrm{HT}_{1 \mathrm{~B}}$ receptors. $5-\mathrm{HT}_{1 \mathrm{~B}}$ receptors are densely expressed in the subiculum, the main output area of the hippocampus (Figure 2C), and are believed to play an important role in memory function. ${ }^{153,154}$ Thus, vortioxetine, through its partial agonism at $5-\mathrm{HT}_{1 \mathrm{~B}}$ receptors, might have a positive outcome on memory processing. Additional studies are needed to confirm this hypothesis, as well as to test the potential role of vortioxetine's other receptor activities on hippocampal function.

Acute and sub-chronic treatments with vortioxetine also increase extracellular levels of NE and HA in the ventral hippocampus. ${ }^{149,155}$ Increases in DA and ACh levels have also been observed, but only after the acute treatment. ${ }^{148,149}$ Furthermore, a study in rat hippocampal slices showed that vortioxetine disinhibited CA1 pyramidal neurons in response to 5 -HT, again most likely through its $5-\mathrm{HT}_{3}$ receptor antagonism, whereas escitalopram had no effect on this measure. ${ }^{82}$ In line with these findings, several results indicate that vortioxetine promotes glutamate-dependent neuronal plasticity in the hippocampus to a greater degree than SSRIs. For example, vortioxetine, unlike escitalopram, produced a significant increase in LTP in rat hippocampal slices. ${ }^{82}$ Furthermore, in mice aged 12 months, chronic treatment with vortioxetine activated neuronal plasticityrelated genes and improved hippocampus-dependent, visual-spatial memory deficits, whereas fluoxetine had no effect on these readouts. ${ }^{156}$ In another study performed in rats, vortioxetine increased cell proliferation in the hippocampal DG faster than fluoxetine ( 3 days for vortioxetine compared to 10 days for fluoxetine). ${ }^{157}$ Vortioxetine also produced a larger degree of hippocampal dendritic branching than fluoxetine after 2 weeks of dosing in mice. ${ }^{158}$ In line with these mechanistic data, vortioxetine showed pro-cognitive effects in hippocampus-dependent cognition models in rodents, such as footshock-induced fear conditioning and spontaneous alternation (Table 2). However, these findings are relatively recent, and vortioxetine has been studied less than other serotonergic drugs and receptors. For instance, there have been only 3 behavioral studies on the effects of vortioxetine on hippocampal-dependent memory versus 16 studies on $5-\mathrm{HT}_{1 \mathrm{~A}}$ receptors and 10 studies on $5-\mathrm{HT}_{2}$ receptors with different 
pharmacological and genetic approaches (Table 2). Thus, confirmation and expansion of these results are important.

Taken together, vortioxetine's effects in the hippocampus support the notion that its antidepressant activities and pro-cognitive effects are mediated, at least to some extent, through increased glutamate neurotransmission and increased neuroplasticity. It is important to note that although increased glutamate neurotransmission is thought to favor neuronal plasticity, it is also clear that excessive glutamate release (for instance, in relation to stress) can be neurotoxic (reviewed in Sanacora and Banasr $^{159}$ and Sanacora et $\left.a l^{160}\right)$. Vortioxetine's effects on glutamate are limited to enhanced neuronal function. This has been shown in microdialysis studies, where the treatment with vortioxetine did not result in measureable changes in extracellular glutamate in the ventral hippocampus and prefrontal cortex. ${ }^{161}$

In conclusion, vortioxetine's combined inhibition of 5-HT reuptake and 5-HT receptor modulation results in a differentiated effect on hippocampus function and hippocampal-dependent behavior compared to SSRIs. The full implication of vortioxetine's modulation of multiple neurotransmitter systems on its antidepressant and pro-cognitive potential is complex and remains to be elucidated in future studies.

\section{Overall Conclusion and Future Directions}

There is considerable evidence to support the notion that the hippocampus plays an important role in emotional and cognitive processing, and that both of these functions are affected in patients with MDD. SSRIs and SNRIs are the predominant pharmacotherapies for treating MDD, and their enhancing effects on 5-HT levels are believed to be important for their therapeutic efficacy. However, the biological processes that lead to the recovery from the depressive state remain poorly understood. Furthermore, despite several decades of extensive research, the role of 5 -HT in regulating hippocampal function in normal or disease states is not well understood, probably due to the high degree of complexity of the serotonergic system.

Multiple classes of 5-HT receptors are often co-expressed on the same cell types with functions that can either be complementary or opposing, and little is known about the interactions between different 5-HT receptors subtypes. Furthermore, the majority of 5-HT receptors in the hippocampus are found on both principal glutamatergic cells and GABAergic interneurons. The 2 known exceptions are the $5-\mathrm{HT}_{3}$ receptor subclass, which has only been found on interneurons, and the $5-\mathrm{HT}_{4}$ receptor subclass, which has only been found on pyramidal cells. $5-\mathrm{HT}_{3}$ receptors are also the only non-G -protein-coupled receptors that function as a ligand-gated ion channel. The impact of the unique expression pattern and effector system of the $5-\mathrm{HT}_{3}$ receptor remains to be elucidated. However, given the key role that $5-\mathrm{HT}_{3}$ receptor antagonism appears to have in mediating the pharmacological effects of vortioxetine, at least in preclinical behavioral, electrophysiology, and microdialysis studies, ${ }^{148,157,162}$ this receptor subtype might have an important role in the hippocampus. $5-\mathrm{HT}_{4}$ receptors have been less studied, and understanding their function in the hippocampus remains to be elucidated in further detail.

The effect of SSRIs on hippocampal function remains poorly defined. While SSRIs have the potential to normalize hippocampal plasticity under stress conditions and to treat mood symptoms in MDD, their effects on cognitive function are less clear. Since SSRIs do not possess selectivity for 5-HT receptor subtypes, their efficacy might be weakened due to opposing activities of different 5-HT receptor subtypes. In this context, multitarget drugs or combination therapies might be a better strategy to modulate both emotional and cognitive processes in the hippocampus. Future insights into interactions between different serotonergic subtypes might therefore lead to novel treatment options for the treatment of MDD.

\section{Disclosures}

All authors are full-time employees of H. Lundbeck A/S.

\section{REFERENCES:}

1. Femenia T, Gomez-Galan M, Lindskog M, Magara S. Dysfunctional hippocampal activity affects emotion and cognition in mood disorders. Brain Res. 2012; 1476: 58-70.

2. Small SA, Schobel SA, Buxton RB, Witter MP, Barnes CA. A pathophysiological framework of hippocampal dysfunction in ageing and disease. Nat Rev Neurosci. 2011; 12(10): 585-601.

3. Bell-McGinty S, Butters MA, Meltzer CC, Greer PJ, Reynolds CF 3rd, Becker JT. Brain morphometric abnormalities in geriatric depression: long-term neurobiological effects of illness duration. Am J Psychiatry. 2002; 159(8): 1424-1427.

4. Bremner JD, Narayan M, Anderson ER, Staib LH, Miller HL, Charney DS. Hippocampal volume reduction in major depression. Am J Psychiatry. 2000; 157(1): 115-118.

5. Frodl TS, Koutsouleris N, Bottlender R, et al. Depression-related variation in brain morphology over 3 years: effects of stress? Arch Gen Psychiatry. 2008; 65(10): 1156-1165.

6. Sheline YI, Gado MH, Kraemer HC. Untreated depression and hippocampal volume loss. Am J Psychiatry. 2003; 160(8): 1516-1518.

7. Videbech P, Ravnkilde B. Hippocampal volume and depression: a meta-analysis of MRI studies. Am J Psychiatry. 2004; 161(11): 1957-1966.

8. MacQueen GM, Campbell S, McEwen BS, et al. Course of illness, hippocampal function, and hippocampal volume in major depression. Proc Natl Acad Sci U S A. 2003; 100(3): 1387-1392.

9. Gorwood P, Corruble E, Falissard B, Goodwin GM. Toxic effects of depression on brain function: impairment of delayed recall and the cumulative length of depressive disorder in a large sample of depressed outpatients. Am J Psychiatry. 2008; 165(6): 731-739. 
10. Harvey PO, Fossati P, Pochon JB, et al. Cognitive control and brain resources in major depression: an fMRI study using the n-back task. Neuroimage. 2005; 26(3): 860-869.

11. Walsh ND, Williams SC, Brammer MJ, et al. A longitudinal functional magnetic resonance imaging study of verbal working memory in depression after antidepressant therapy. Biol Psychiatry. 2007; 62(11): 1236-1243.

12. Hammar A, Ardal G. Cognitive functioning in major depression-a summary. Front Hum Neurosci. 2009; 3: 26.

13. Lee RS, Hermens DF, Porter MA, Redoblado-Hodge MA. A meta-analysis of cognitive deficits in first-episode major depressive disorder. J Affect Disord. 2012; 140(2): 113-124.

14. Porter RJ, Bourke C, Gallagher P. Neuropsychological impairment in major depression: its nature, origin and clinical significance. Aust N Z J Psychiatry. 2007; 41(2): 115-128.

15. Hasselbalch BJ, Knorr U, Kessing LV. Cognitive impairment in the remitted state of unipolar depressive disorder: a systematic review. J Affect Disord. 2011; 134(1-3): 20-31.

16. Campbell S, MacQueen G. The role of the hippocampus in the pathophysiology of major depression. J Psychiatry Neurosci. 2004; 29(6): 417-426.

17. Biringer E, Rongve A, Lund A. A review of modern antidepressants' effects on neurocognitive function. Cur Psychiatr Rev. 2009; 5(3): 164-174.

18. McIntyre RS, Cha DS, Soczynska JK, et al. Cognitive deficits and functional outcomes in major depressive disorder: determinants, substrates, and treatment interventions. Depress Anxiety. 2013; 30(6): 515-527.

19. Vythilingam M, Vermetten E, Anderson GM, et al. Hippocampal volume, memory, and cortisol status in major depressive disorder: effects of treatment. Biol Psychiatry. 2004; 56(2): 101-112.

20. Fanselow MS, Dong HW. Are the dorsal and ventral hippocampus functionally distinct structures? Neuron. 2010; 65(1): 7-19.

21. Moser MB, Moser EI. Functional differentiation in the hippocampus. Hippocampus. 1998; 8(6): 608-619.

22. Poppenk J, Evensmoen HR, Moscovitch M, Nadel L. Long-axis specialization of the human hippocampus. Trends Cogn Sci. 2013; 17(5): 230-240.

23. O'Leary OF, Cryan JF. A ventral view on antidepressant action: roles for adult hippocampal neurogenesis along the dorsoventral axis. Trends Pharmacol Sci. 2014; 35(12): 675-687.

24. Moser E, Moser MB, Andersen P. Spatial learning impairment parallels the magnitude of dorsal hippocampal lesions, but is hardly present following ventral lesions. J Neurosci. 1993; 13(9): 3916-3925.

25. Pothuizen HH, Zhang WN, Jongen-Relo AL, Feldon J, Yee BK. Dissociation of function between the dorsal and the ventral hippocampus in spatial learning abilities of the rat: a withinsubject, within-task comparison of reference and working spatial memory. Eur J Neurosci. 2004; 19(3): 705-712.

26. Bannerman DM, Grubb M, Deacon RM, Yee BK, Feldon J, Rawlins JN. Ventral hippocampal lesions affect anxiety but not spatial learning. Behav Brain Res. 2003; 139(1-2): 197-213.

27. Bannerman DM, Rawlins JN, McHugh SB, et al. Regional dissociations within the hippocampus-memory and anxiety. Neurosci Biobehav Rev. 2004; 28(3): 273-283.

28. Kjelstrup KG, Tuvnes FA, Steffenach HA, Murison R, Moser EI, Moser MB. Reduced fear expression after lesions of the ventral hippocampus. Proc Natl Acad Sci US A. 2002; 99(16): 10825-10830.

29. Rudy JW, Matus-Amat P. The ventral hippocampus supports a memory representation of context and contextual fear conditioning: implications for a unitary function of the hippocampus. Behav Neurosci. 2005; 119(1): 154-163.

30. Ramon y Cajal S. Histologie du Systeme Nerveux de l'Homme et des Vertbré Vol II. Paris: Maloine; 1911.
31. Lorente de Nó R. Studies of the structure of the cerebral cortex. II. Continuation of the study of the ammonic system. Journal für Psychologie und Neurologie. 1934; 46: 113-177.

32. Lavenex P. Functional anatomy, development and pathology of the hippocampus. In: Bartsch T ed. The Clinical Neurobiology of the Hippocampus: An Integrative View. Oxford, UK: Oxford University Press; 2012: 10-38.

33. Freund TF, Buzsáki G. Interneurons of the hippocampus. Hippocampus. 1996; 6(4): 347-470.

34. Parra P, Gulyas AI, Miles R. How many subtypes of inhibitory cells in the hippocampus? Neuron. 1998; 20(5): 983-993.

35. Ribak CE, Nitsch R, Seress L. Proportion of parvalbumin-positive basket cells in the GABAergic innervation of pyramidal and granule cells of the rat hippocampal formation. J Comp Neurol. 1990; 300(4): 449-461.

36. Sloviter RS. Calcium-binding protein (calbindin-D28k) and parvalbumin immunocytochemistry: localization in the rat hippocampus with specific reference to the selective vulnerability of hippocampal neurons to seizure activity. J Comp Neurol. 1989; 280(2): 183-196.

37. Aznar S, Qian Z, Shah R, Rahbek B, Knudsen GM. The 5-HT1A serotonin receptor is located on calbindin- and parvalbumincontaining neurons in the rat brain. Brain Res. 2003; 959(1): 58-67.

38. Gulyas AI, Hajos N, Freund TF. Interneurons containing calretinin are specialized to control other interneurons in the rat hippocampus. J Neurosci. 1996; 16(10): 3397-3411.

39. Berumen LC, Rodriguez A, Miledi R, Garcia-Alcocer G. Serotonin receptors in hippocampus. Scientific WorldJournal. 2012; 2012 823493.

40. Oleskevich S, Descarries L, Watkins KC, Seguela P, Daszuta A. Ultrastructural features of the serotonin innervation in adult rat hippocampus: an immunocytochemical description in single and serial thin sections. Neuroscience. 1991; 42(3): 777-791.

41. Umbriaco D, Garcia S, Beaulieu C, Descarries L. Relational features of acetylcholine, noradrenaline, serotonin and GABA axon terminals in the stratum radiatum of adult rat hippocampus (CA1). Hippocampus. 1995; 5(6): 605-620.

42. Vizi ES, Kiss JP. Neurochemistry and pharmacology of the major hippocampal transmitter systems: synaptic and nonsynaptic interactions. Hippocampus. 1998; 8(6): 566-607.

43. Aghajanian GK, Sanders-Bush E. Serotonin. In: Davis KL, Charney D, Coyle JT, Nemeroff C eds. Neuropsychopharmacology: The Fifth Generation of Progress. Philadelphia: Lippincott, Williams, \& Wilkins; 2002.

44. Glennon RA, Dukat M, Westkaemper RB. Serotonin receptor subtypes and ligands. In: Bloom FE, Kupfer DJ eds. Psychopharmacology: The Fourth Generation of Progress. New York: Raven Press; 2000.

45. Herrick-Davis K. Functional significance of serotonin receptor dimerization. Exp Brain Res. 2013; 230(4): 375-386.

46. Gonzalez-Maeso J, Ang RL, Yuen T, et al. Identification of a serotonin/glutamate receptor complex implicated in psychosis. Nature. 2008; 452(7183): 93-97.

47. Naumenko VS, Popova NK, Lacivita E, Leopoldo M, Ponimaskin EG. Interplay between serotonin 5-HT1A and 5-HT7 receptors in depressive disorders. CNS Neurosci Ther. 2014; 20(7): 582-590.

48. Jarrard LE. On the role of the hippocampus in learning and memory in the rat. Behav Neural Biol. 1993; 60(1): 9-26.

49. Squire LR. Memory and the hippocampus: a synthesis from findings with rats, monkeys, and humans. Psychol Rev. 1992; 99(2): 195-231.

50. Knierim JJ, Hamilton DA. Framing spatial cognition: neural representations of proximal and distal frames of reference and their roles in navigation. Physiological Rev. 2011; 91(4): 1245-1279. 
51. Luscher C, Jan LY, Stoffel M, Malenka RC, Nicoll RA. G proteincoupled inwardly rectifying $\mathrm{K}+$ channels (GIRKs) mediate postsynaptic but not presynaptic transmitter actions in hippocampal neurons. Neuron. 1997; 19(3): 687-695.

52. Pompeiano M, Palacios JM, Mengod G. Distribution and cellular localization of mRNA coding for 5-HT1A receptor in the rat brain: correlation with receptor binding. J Neurosci. 1992; 12(2): 440-453.

53. Andrade R, Nicoll RA. Pharmacologically distinct actions of serotonin on single pyramidal neurones of the rat hippocampus recorded in vitro. J Physiol. 1987; 394: 99-124.

54. Beck SG, Clarke WP, Goldfarb J. Spiperone differentiates multiple 5-hydroxytryptamine responses in rat hippocampal slices in vitro. Eur J Pharmacol. 1985; 116(1-2): 195-197.

55. Chaput Y, Araneda RC, Andrade R. Pharmacological and functional analysis of a novel serotonin receptor in the rat hippocampus. Eur J Pharmacol. 1990; 182(3): 441-456.

56. Haddjeri N, Blier P, de Montigny C. Long-term antidepressant treatments result in a tonic activation of forebrain 5-HT1A receptors. J Neursci. 1998; 18(23): 10150-10156.

57. Johnston A, McBain CJ, Fisahn A. 5-Hydroxytryptamine1A receptor-activation hyperpolarizes pyramidal cells and suppresses hippocampal gamma oscillations via Kir3 channel activation. J Physiol. 2014; 592(Pt 19): 4187-4199.

58. Kasamo K, Suzuki T, Tada K, et al. Endogenous 5-HT tonically inhibits spontaneous firing activity of dorsal hippocampus CA1 pyramidal neurons through stimulation of 5-HT(1A) receptors in quiet awake rats: in vivo electrophysiological evidence. Neuropsychopharmacology. 2001; 24(2): 141-151.

59. Tada K, Kasamo K, Suzuki T, Matsuzaki Y, Kojima T. Endogenous 5-HT inhibits firing activity of hippocampal CA1 pyramidal neurons during conditioned fear stress-induced freezing behavior through stimulating 5-HT1A receptors. Hippocampus. 2004; 14(2): 143-147.

60. Llado-Pelfort L, Santana N, Ghisi V, Artigas F, Celada P. 5-HT1A receptor agonists enhance pyramidal cell firing in prefrontal cortex through a preferential action on GABA interneurons. Cereb Cortex. 2012; 22(7): 1487-1497.

61. Haider S, Khaliq S, Tabassum S, Haleem DJ. Role of somatodendritic and postsynaptic 5-HT(1)A receptors on learning and memory functions in rats. Neurochem Res. 2012; 37(10): 2161-2166.

62. Newman-Tancredi A, Martel JC, Assie MB, et al. Signal transduction and functional selectivity of F15599, a preferential post-synaptic 5-HT1A receptor agonist. Br J Pharmacol. 2009; 156(2): 338-353.

63. Boschert U, Amara DA, Segu L, Hen R. The mouse 5-hydroxytryptamine1B receptor is localized predominantly on axon terminals. Neuroscience. 1994; 58(1): 167-182.

64. Bruinvels AT, Landwehrmeyer B, Gustafson EL, et al. Localization of 5-HT1B, 5-HT1D alpha, 5-HT1E and 5-HT1F receptor messenger RNA in rodent and primate brain. Neuropharmacology. 1994; 33(3-4): 367-386.

65. Sari Y, Lefevre K, Bancila M, et al. Light and electron microscopic immunocytochemical visualization of 5-HT1B receptors in the rat brain. Brain Res. 1997; 760(1-2): 281-286.

66. Bruinvels AT, Palacios JM, Hoyer D. Autoradiographic characterisation and localisation of 5-HT1D compared to 5-HT1B binding sites in rat brain. Naunyn Schmiedebergs Arch Pharmacol. 1993; 347(6): 569-582.

67. Xie Z, Lee SP, O'Dowd BF, George SR. Serotonin 5-HT1B and 5-HT1D receptors form homodimers when expressed alone and heterodimers when co-expressed. FEBS Lett. 1999; 456(1): 63-67.

68. Boeijinga PH, Boddeke HW. Serotonergic modulation of neurotransmission in the rat subicular cortex in vitro: a role for 5-HT1B receptors. Naunyn Schmiedebergs Arch Pharmacol. 1993; 348(6): 553-557.
69. Mlinar B, Falsini C, Corradetti R. Pharmacological characterization of 5 -HT $(1 \mathrm{~B})$ receptor-mediated inhibition of local excitatory synaptic transmission in the CA1 region of rat hippocampus. Br J Pharmacol. 2003; 138(1): 71-80.

70. Hu XJ, Wang FH, Stenfors C, Ogren SO, Kehr J. Effects of the 5-HT1B receptor antagonist NAS-181 on extracellular levels of acetylcholine, glutamate and GABA in the frontal cortex and ventral hippocampus of awake rats: a microdialysis study. Eur Neuropsychopharmacol. 2007; 17(9): 580-586.

71. Bombardi C. Neuronal localization of 5-HT2A receptor immunoreactivity in the rat hippocampal region. Brain Res Bull. 2012; 87(2-3): 259-273.

72. Cornea-Hebert V, Riad M, Wu C, Singh SK, Descarries L. Cellular and subcellular distribution of the serotonin 5-HT2A receptor in the central nervous system of adult rat. J Comp Neurol. 1999; 409(2): 187-209.

73. Luttgen M, Ove Ogren S, Meister B. Chemical identity of 5-HT2A receptor immunoreactive neurons of the rat septal complex and dorsal hippocampus. Brain Res. 2004; 1010(1-2): 156-165.

74. Shen RY, Andrade R. 5-Hydroxytryptamine2 receptor facilitates GABAergic neurotransmission in rat hippocampus. J Pharmacol Exp Ther. 1998; 285(2): 805-812.

75. Wang RY, Arvanov VL. M100907, a highly selective 5-HT2A receptor antagonist and a potential atypical antipsychotic drug, facilitates induction of long-term potentiation in area CA1 of the rat hippocampal slice. Brain Res. 1998; 779(1-2): 309-313.

76. Morales M, Battenberg E, de Lecea L, Bloom FE. The type 3 serotonin receptor is expressed in a subpopulation of GABAergic neurons in the rat neocortex and hippocampus. Brain Res. 1996; 731(1-2): 199-202.

77. Morales M, Battenberg E, de Lecea L, Sanna PP, Bloom FE. Cellular and subcellular immunolocalization of the type 3 serotonin receptor in the rat central nervous system. Brain Res Mol Brain Res. 1996; 36(2): 251-260.

78. Bloom FE, Morales M. The central 5-HT3 receptor in CNS disorders. Neurochem Res. 1998; 23(5): 653-659.

79. Morales M, Bloom FE. The 5-HT3 receptor is present in different subpopulations of GABAergic neurons in the rat telencephalon. J Neurosci. 1997; 17(9): 3157-3167.

80. Kawa K. Distribution and functional properties of 5-HT3 receptors in the rat hippocampal dentate gyrus: a patch-clamp study. J Neurophysiol. 1994; 71(5): 1935-1947.

81. McMahon LL, Kauer JA. Hippocampal interneurons are excited via serotonin-gated ion channels. J Neurophysiol. 1997; 78(5): 2493-2502.

82. Dale E, Zhang H, Leiser SC, et al. Vortioxetine disinhibits pyramidal cell function and enhances synaptic plasticity in the rat hippocampus. J Psychopharmacol. 2014; 28(10): 891-902.

83. Passani MB, Pugliese AM, Azzurrini M, Corradetti R. Effects of DAU 6215, a novel 5-hydroxytryptamine3 (5-HT3) antagonist on electrophysiological properties of the rat hippocampus. Br J Pharmacol. 1994; 112(2): 695-703.

84. Ropert N, Guy N. Serotonin facilitates GABAergic transmission in the CA1 region of rat hippocampus in vitro. J Physiol. 1991; 441(1): 121-136.

85. Turner TJ, Mokler DJ, Luebke JI. Calcium influx through presynaptic 5-HT3 receptors facilitates GABA release in the hippocampus: in vitro slice and synaptosome studies. Neuroscience. 2004; 129(3): 703-718.

86. Reznic J, Staubli U. Effects of 5-HT3 receptor antagonism on hippocampal cellular activity in the freely moving rat. J Neurophysiol. 1997; 77(1): 517-521.

87. Staubli U, Otaky N. Serotonin controls the magnitude of LTP induced by theta bursts via an action on NMDA-receptor-mediated responses. Brain Res. 1994; 643(1-2): 10-16. 
88. Staubli U, Xu FB. Effects of 5-HT3 receptor antagonism on hippocampal theta rhythm, memory, and LTP induction in the freely moving rat. J Neurosci. 1995; 15(3 Pt 2): 2445-2452.

89. Vilaro MT, Cortes R, Mengod G. Serotonin 5-HT4 receptors and their mRNAs in rat and guinea pig brain: distribution and effects of neurotoxic lesions. J Comp Neurol. 2005; 484(4): 418-439.

90. Waeber C, Sebben M, Nieoullon A, Bockaert J, Dumuis A. Regional distribution and ontogeny of 5-HT4 binding sites in rodent brain. Neuropharmacology. 1994; 33(3-4): 527-541.

91. Peñas-Cazorla R, Vilaró MT. Serotonin 5-HT receptors and forebrain cholinergic system: receptor expression in identified cel populations. Brain Struct Funct. In press. DOI: 10.1007/s00429014-0864-z.

92. Chapin EM, Haj-Dahmane S, Torres G, Andrade R. The 5-HT(4) receptor-induced depolarization in rat hippocampal neurons is mediated by cAMP but is independent of I(h). Neurosci Lett. 2002; 324(1): 1-4.

93. Mlinar B, Mascalchi S, Mannaioni G, Morini R, Corradetti R. 5-HT4 receptor activation induces long-lasting EPSP-spike potentiation in CA1 pyramidal neurons. Eur J Nneurosci. 2006; 24(3): 719-731.

94. Matsumoto M, Togashi H, Mori K, et al. Evidence for involvement of central 5-HT(4) receptors in cholinergic function associated with cognitive processes: behavioral, electrophysiological, and neurochemical studies. J Pharmacol Exp Ther. 2001; 296(3): 676-682.

95. Oliver KR, Kinsey AM, Wainwright A, Sirinathsinghji DJ. Localization of 5-ht(5A) receptor-like immunoreactivity in the rat brain. Brain Res. 2000; 867(1-2): 131-142.

96. Kinsey AM, Wainwright A, Heavens R, Sirinathsinghji DJ, Oliver KR. Distribution of 5-ht(5A), 5-ht(5B), 5-ht(6) and 5-HT(7) receptor mRNAs in the rat brain. Brain Res Mol Brain Res. 2001; 88(1-2): 194-198.

97. Gerard C, Martres MP, Lefevre K, et al. Immuno-localization of serotonin 5-HT6 receptor-like material in the rat central nervous system. Brain Res. 1997; 746(1-2): 207-219.

98. de Jong I, Helboe L. Distribution of serotonin receptor 5-HT6 mRNA in selected neuronal populations in rat brain: a doublelabelling in situ hybridization study. Alzheimer's \& Dementia. 2014; 10(4 Suppl): 925-926.

99. West PJ, Marcy VR, Marino MJ, Schaffhauser H. Activation of the 5-HT(6) receptor attenuates long-term potentiation and facilitates GABAergic neurotransmission in rat hippocampus. Neuroscience. 2009; 164(2): 692-701.

100. Schechter LE, Lin Q, Smith DL, et al. Neuropharmacological profile of novel and selective 5-HT6 receptor agonists: WAY-181187 and WAY-208466. Neuropsychopharmacol. 2008; 33(6): 1323-1335.

101. Dawson LA, Nguyen HQ, Li P. The 5-HT(6) receptor antagonist SB-271046 selectively enhances excitatory neurotransmission in the rat frontal cortex and hippocampus. Neuropsychopharmacology. 2001; 25(5): 662-668.

102. Pehrson AL, Sanchez C. Altered gamma-aminobutyric acid neurotransmission in major depressive disorder: a critical review of the supporting evidence and the influence of serotonergic antidepressants. Drug Des Devel Ther. 2015; 9: 603-624.

103. Wilkinson D, Windfeld K, Colding-Jorgensen E. Safety and efficacy of idalopirdine, a 5-HT6 receptor antagonist, in patients with moderate Alzheimer's disease (LADDER): a randomised, doubleblind, placebo-controlled phase 2 trial. Lancet Neurol. 2014; 13(11): 1092-1099.

104. Neumaier JF, Sexton TJ, Yracheta J, Diaz AM, Brownfield M. Localization of 5-HT(7) receptors in rat brain by immunocytochemistry, in situ hybridization, and agonist stimulated cFos expression. J Chem Neuroanat. 2001; 21(1): $63-73$.
105. Garcia-Alcocer G, Segura LC, Garcia Pena M, Martinez-Torres A, Miledi R. Ontogenetic distribution of 5-HT2C, 5-HT5A, and 5-HT7 receptors in the rat hippocampus. Gene Expr. 2006; 13(1): 53-57.

106. Kobe F, Guseva D, Jensen TP, et al. 5-HT7R/G12 signaling regulates neuronal morphology and function in an agedependent manner. J Neurosci. 2012; 32(9): 2915-2930.

107. Muneoka KT, Takigawa M. 5-Hydroxytryptamine7 (5-HT7) receptor immunoreactivity-positive 'stigmoid body'-like structure in developing rat brains. Int J Dev Neurosci. 2003; 21(3): 133-143.

108. Ciranna L. Serotonin as a modulator of glutamate- and GABAmediated neurotransmission: implications in physiological functions and in pathology. Curr Neuropharmacol. 2006; 4(2): 101-114.

109. Costa L, Trovato C, Musumeci SA, Catania MV, Ciranna L. 5-HT (1A) and 5-HT(7) receptors differently modulate AMPA receptormediated hippocampal synaptic transmission. Hippocampus. 2012 22(4): 790-801.

110. Gill CH, Soffin EM, Hagan JJ, Davies CH. 5-HT7 receptors modulate synchronized network activity in rat hippocampus. Neuropharmacology. 2002; 42(1): 82-92.

111. Tokarski K, Zahorodna A, Bobula B, Hess G. 5-HT7 receptors increase the excitability of rat hippocampal CA1 pyramidal neurons. Brain Res. 2003; 993(1-2): 230-234.

112. Tokarski K, Kusek M, Hess G. 5-HT7 receptors modulate GABAergic transmission in rat hippocampal CA1 area. J Physiol Pharmacol. 2011; 62(5): 535-540.

113. Gasbarri A, Pompili A. Serotonergic 5-HT7 receptors and cognition. Rev Neurosci. 2014; 25(3): 311-323.

114. Meneses A. Memory formation and memory alterations: 5-HT6 and 5-HT7 receptors, novel alternative. Rev Neurosci. 2014; 25(3): 325-356.

115. Chaput Y, Lesieur P, de Montigny C. Effects of short-term serotonin depletion on the efficacy of serotonin neurotransmission: electrophysiological studies in the rat central nervous system. Synapse. 1990; 6(4): 328-337.

116. Ferraro G, Montalbano ME, Sardo P, La Grutta V. Lateral habenula and hippocampus: a complex interaction raphe cells-mediated. J Neural Transm. 1997; 104(6-7): 615-631.

117. Segal M. Physiological and pharmacological evidence for a serotonergic projection to the hippocampus. Brain Res. 1975; 94(1): 115-131.

118. Segal M. 5-HT antagonists in rat hippocampus. Brain Res. 1976; 103(1): 161-166.

119. Andrade R, Chaput Y. 5-Hydroxytryptamine4-like receptors mediate the slow excitatory response to serotonin in the rat hippocampus. J Pharmacol Exp Ther. 1991; 257(3): 930-937.

120. Piguet $\mathrm{P}$, Galvan M. Transient and long-lasting actions of $5-\mathrm{HT}$ on rat dentate gyrus neurones in vitro. J Physiol. 1994; 481 (Pt 3): 629-639.

121. Cremers TI, Rea K, Bosker FJ, et al. Augmentation of SSRI effects on serotonin by 5 -HT2C antagonists: mechanistic studies. Neuropsychopharmacology. 2007; 32(7): 1550-1557.

122. Haider S, Khaliq S, Ahmed SP, Haleem DJ. Long-term tryptophan administration enhances cognitive performance and increases 5HT metabolism in the hippocampus of female rats. Amino Acids. 2006; 31(4): 421-425.

123. Hervas I, Artigas F. Effect of fluoxetine on extracellular 5 -hydroxytryptamine in rat brain. Role of 5-HT autoreceptors. Eur J Pharmacol. 1998; 358(1): 9-18.

124. Le Poul E, Boni C, Hanoun N, et al. Differential adaptation of brain 5-HT1A and 5-HT1B receptors and 5-HT transporter in rats treated chronically with fluoxetine. Neuropharmacology. 2000; 39(1): 110-122.

125. Blier P, de Montigny C, Chaput Y. A role for the serotonin system in the mechanism of action of antidepressant treatments: preclinical evidence. J Clin Psychiatry. 1990; 51(Suppl): 14-20; discussion 21 . 
126. Chaput Y, de Montigny C, Blier P. Presynaptic and postsynaptic modifications of the serotonin system by long-term administration of antidepressant treatments. An in vivo electrophysiologic study in the rat. Neuropsychopharmacology. 1991; 5(4): 219-229.

127. Malenka RC, Nicoll RA. Long-term potentiation-a decade of progress? Science. 1999; 285(5435): 1870-1874.

128. Corradetti R, Ballerini L, Pugliese AM, Pepeu G. Serotonin blocks the long-term potentiation induced by primed burst stimulation in the CA1 region of rat hippocampal slices. Neuroscience. 1992; 46(3): 511-518.

129. Mnie-Filali O, El Mansari M, Espana A, Sanchez C, Haddjeri N. Allosteric modulation of the effects of the 5-HT reuptake inhibitor escitalopram on the rat hippocampal synaptic plasticity. Neurosci Lett. 2006; 395(1): 23-27.

130. Ryan B, Musazzi L, Mallei A, et al. Remodelling by early-life stress of NMDA receptor-dependent synaptic plasticity in a geneenvironment rat model of depression. Int $J$ Neuropsychopharmacol. 2009; 12(4): 553-559.

131. Shakesby AC, Anwyl R, Rowan MJ. Overcoming the effects of stress on synaptic plasticity in the intact hippocampus: rapid actions of serotonergic and antidepressant agents. J Neurosci. 2002; 22(9): 3638-3644.

132. Stewart CA, Reid IC. Repeated ECS and fluoxetine administration have equivalent effects on hippocampal synaptic plasticity. Psychopharmacology (Berl). 2000; 148(3): 217-223.

133. Pittenger C, Duman RS. Stress, depression, and neuroplasticity: a convergence of mechanisms. Neuropsychopharmacology. 2008; 33(1): 88-109.

134. Popoli M, Gennarelli M, Racagni G. Modulation of synaptic plasticity by stress and antidepressants. Bipolar Disord. 2002; 4(3): 166-182.

135. Holderbach R, Clark K, Moreau JL, Bischofberger J, Normann C. Enhanced long-term synaptic depression in an animal model of depression. Biol Psychiatry. 2007; 62(1): 92-100.

136. Matsumoto M, Tachibana K, Togashi H, et al. Chronic treatment with milnacipran reverses the impairment of synaptic plasticity induced by conditioned fear stress. Psychopharmacology (Berl). 2005; 179(3): 606-612.

137. Godlewska BR, Norbury R, Selvaraj S, Cowen PJ, Harmer CJ. Shortterm SSRI treatment normalises amygdala hyperactivity in depressed patients. Psychol Med. 2012; 42(12): 2609-2617.

138. Herzallah MM, Moustafa AA, Natsheh JY, et al. Depression impairs learning, whereas the selective serotonin reuptake inhibitor, paroxetine, impairs generalization in patients with major depressive disorder. J Affect Disord. 2013; 151(2): 484-492.

139. Olivier B. Serotonin: a never-ending story. Eur J Pharmacol. 2015; 753: $2-18$.

140. Kirchhoff VD, Nguyen HT, Soczynska JK, Woldeyohannes HO, McIntyre RS. Discontinued psychiatric drugs in 2008. Expert Opin Investig Drugs. 2009; 18(10): 1431-1443.

141. Westrich L, Pehrson A, Zhong H, et al. In vitro and in vivo effects of the multimodal antidepressant vortioxetine ( $\mathrm{Lu} \mathrm{AA21004)}$ at human and rat targets. Int J Psych Clin Pract. 2012; 5(Suppl 1): 47.

142. Bang-Andersen B, Ruhland T, Jorgensen M, et al. Discovery of 1-[2-(2,4-dimethylphenylsulfanyl)phenyl]piperazine ( $\mathrm{Lu}$ AA21004): a novel multimodal compound for the treatment of major depressive disorder. J Med Chem. 2011; 54(9): 3206-3221.

143. Katona C, Hansen T, Olsen CK. A randomized, double-blind, placebocontrolled, duloxetine-referenced, fixed-dose study comparing the efficacy and safety of Lu AA21004 in elderly patients with major depressive disorder. Int Clin Psychopharmacol. 2012; 27(4): 215-223.

144. McIntyre RS, Lophaven S, Olsen CK. A randomized, double-blind, placebo-controlled study of vortioxetine on cognitive function in depressed adults. Int J Neuropsychopharmacol. 2014; 17(10): 1557-1567.
145. Mahableshwarkar AR, Zajecka J, Jacobson W, Chen Y, Keefe RS. A randomized, placebo-controlled, active-reference, double-blind, flexible-dose study of the efficacy of vortioxetine on cognitive function in major depressive disorder. Neuropsychopharmacology. 2015; 40(8): 2025-2037.

146. Browning M, Smith J, Conen S, et al. Vortioxetine reduces BOLD signal during performance of the N-Back task in subjects remitted from depression and healthy control participants. Neuropsychopharm. 2014; 39(Supplement 1): S480.

147. Sanchez C, Asin KE, Artigas F. Vortioxetine, a novel antidepressant with multimodal activity: Review of preclinical and clinical data. Pharmacol Ther. 2015; 145: 43-57.

148. Mork A, Pehrson A, Brennum LT, et al. Pharmacological effects of Lu AA21004: a novel multimodal compound for the treatment of major depressive disorder. J Pharmacol Exp Ther. 2012; 340(3): 666-675.

149. Pehrson AL, Cremers T, Betry C, et al. Lu AA21004, a novel multimodal antidepressant, produces regionally selective increases of multiple neurotransmitters-a rat microdialysis and electrophysiology study. Eur Neuropsychopharmacol. 2013; 23(2): 133-145.

150. Puig MV, Santana N, Celada P, Mengod G, Artigas F. In vivo excitation of GABA interneurons in the medial prefrontal cortex through 5-HT3 receptors. Cereb Cortex. 2004; 14(12): 1365-1375.

151. Riga MS, Celada P, Sanchez C, Artigas F. Cortical and hippocampal microcircuits involved in the mechanism of action of the new antidepressant drug vortioxetine. Neuropsychopharm. 2014; 39 (Supplement 1): S632.

152. El Mansari M, Lecours M, Blier P. Effects of acute and sustained administration of vortioxetine on the serotonin system in the hippocampus: electrophysiological studies in the rat brain. Psychopharmacology (Berl). 2015; 232(13): 2343-2352.

153. O’Mara SM, Sanchez-Vives MV, Brotons-Mas JR, O’Hare E. Roles for the subiculum in spatial information processing, memory, motivation and the temporal control of behaviour. Prog Neuropsychopharmacol Biol Psychiatry. 2009; 33(5): 782-790.

154. Sari Y. Serotonin1B receptors: from protein to physiological function and behavior. Neurosci Biobehav Rev. 2004; 28(6): 565-582.

155. Smagin G, Song D, Budac DP, Pehrson A, Li Y, Sanchez C. Chronic treatment with vortioxetine activates the central histaminergic system: a microdialysis study in rats. Biol Psychiatry. 2014; 75(9), Supplement, 391S.

156. Li Y, Abdourahman A, Tamm JA, et al. Reversal of age-associated cognitive deficits is accompanied by increased plasticity-related gene expression after chronic antidepressant administration in middle-aged mice. Pharmacol Biochem Behav. 2015; 135: 70-82.

157. Bétry C, Etiévant A, Pehrson A, Sanchez C, Haddjeri N. Effect of the multimodal acting antidepressant vortioxetine on rat hippocampal plasticity and recognition memory. Prog Neuropsychopharmacol Biol Psychiatry. 2015; 58: 38-46.

158. Guilloux JP, Mendez-David I, Pehrson A, et al. Antidepressant and anxiolytic potential of the multimodal antidepressant vortioxetine (Lu AA21004) assessed by behavioural and neurogenesis outcomes in mice. Neuropharmacology. 2013; 73: 147-159.

159. Sanacora G, Banasr M. From pathophysiology to novel antidepressant drugs: glial contributions to the pathology and treatment of mood disorders. Biol Psychiatry. 2013; 73(12): 1172-1179.

160. Sanacora G, Treccani G, Popoli M. Towards a glutamate hypothesis of depression: an emerging frontier of neuropsychopharmacology for mood disorders. Neuropharmacology. 2012; 62(1): 63-77.

161. Pehrson AL, Sanchez C. Vortioxetine reverses social recognition memory impairments induced by acetylcholine or glutamate dysregulation in rats. Eur Neuropsychopharmacol. 2014; 24(Supplement 2): S369. 
162. Bétry C, Pehrson AL, Etiévant A, Ebert B, Sánchez C, Haddjeri N. The rapid recovery of 5-HT cell firing induced by the antidepressant vortioxetine involves 5-HT(3) receptor antagonism. Int J Neuropsychopharmacol. 2013; 16(5): 1115-1127.

163. Pompeiano M, Palacios JM, Mengod G. Distribution of the serotonin 5-HT2 receptor family mRNAs: comparison between 5-HT2A and 5-HT2C receptors. Brain Res Mol Brain Res. 1994; 23(1-2): 163-178.

164. Haider S, Khaliq S, Haleem DJ. Enhanced serotonergic neurotransmission in the hippocampus following tryptophan administration improves learning acquisition and memory consolidation in rats. Pharmacol Rep. 2007; 59(1): 53-57.

165. Levkovitz Y, Richter-Levin G, Segal M. Effect of 5hydroxytryptophane on behavior and hippocampal physiology in young and old rats. Neurobiol Aging. 1994; 15(5): 635-641.

166. Egashira N, Mishima K, Katsurabayashi S, et al. Involvement of 5-hydroxytryptamine neuronal system in Delta(9)tetrahydrocannabinol-induced impairment of spatial memory. Eur J Pharmacol. 2002; 445(3): 221-229.

167. Inoue T, Kitaichi Y, Koyama T. SSRIs and conditioned fear. Prog Neuropsychopharmacol Biol Psychiatry. 2011; 35(8): 1810-1819.

168. Karabeg MM, Grauthoff S, Kollert SY, et al. 5-HTT deficiency affects neuroplasticity and increases stress sensitivity resulting in altered spatial learning performance in the Morris water maze but not in the Barnes maze. PloS one. $2013 ; \mathbf{8}(10)$ : e78238.

169. Nonkes LJ, de Pooter M, Homberg JR. Behavioural therapy based on distraction alleviates impaired fear extinction in male serotonin transporter knockout rats. J Psychiatry Neurosci. 2012; 37(4): 224-230.

170. Luoni A, Hulsken S, Cazzaniga G, Racagni G, Homberg JR, Riva MA. Behavioural and neuroplastic properties of chronic lurasidone treatment in serotonin transporter knockout rats. Int J Neuropsychopharmacol. 2013; 16(6): 1319-1330.

171. Ampuero E, Stehberg J, Gonzalez D, et al. Repetitive fluoxetine treatment affects long-term memories but not learning. Behav Brain Res. 2013; 247: 92-100.

172. Sass A, Wortwein G. The effect of subchronic fluoxetine treatment on learning and memory in adolescent rats. Behav Brain Res. 2012; 228(1): 169-175.

173. Gumuslu E, Mutlu O, Sunnetci D, et al. The effects of tianeptine, olanzapine and fluoxetine on the cognitive behaviors of unpredictable chronic mild stress-exposed mice. Drug Res. 2013; 63(10): 532-539.

174. Valluzzi JA, Chan K. Effects of fluoxetine on hippocampaldependent and hippocampal-independent learning tasks. Behav Pharmacol. 2007; 18(5-6): 507-513.

175. Heinen M, Hettich MM, Ryan DP, Schnell S, Paesler K, Ehninger D. Adult-onset fluoxetine treatment does not improve behavioral impairments and may have adverse effects on the Ts65Dn mouse model of Down syndrome. Neural Plasticity. 2012; 2012: Article 467251.

176. Myint AM, O'Mahony S, Kubera M, et al. Role of paroxetine in interferon-alpha-induced immune and behavioural changes in male Wistar rats. J Psychopharmacol. 2007; 21(8): 843-850.

177. Wang Y, Neumann M, Hansen K, et al. Fluoxetine increases hippocampal neurogenesis and induces epigenetic factors but does not improve functional recovery after traumatic brain injury. J Neurotrauma. 2011; 28(2): 259-268.

178. Naudon L, Hotte M, Jay TM. Effects of acute and chronic antidepressant treatments on memory performance: a comparison between paroxetine and imipramine. Psychopharmacology (Berl). 2007; 191(2): 353-364.

179. Egashira N, Matsumoto Y, Mishima K, et al. Low dose citalopram reverses memory impairment and electroconvulsive shock-induced immobilization. Pharmacol Biochem Behav. 2006; 83(1): 161-167.
180. Montezinho LP, Miller S, Plath N, et al. The effects of acute treatment with escitalopram on the different stages of contextual fear conditioning are reversed by atomoxetine. Psychopharmacology (Berl). 2010; 212(2): 131-143.

181. Bridoux A, Laloux C, Derambure P, Bordet R, Monaca Charley C. The acute inhibition of rapid eye movement sleep by citalopram may impair spatial learning and passive avoidance in mice. J Neural Transm. 2013; 120(3): 383-389.

182. Jensen JB, du Jardin KG, Song D, et al. Vortioxetine, but not escitalopram or duloxetine, reverses memory impairment induced by central 5-HT depletion in rats: evidence for direct 5-HT receptor modulation. Eur Neuropsychopharmacol. 2014; 24(1): 148-159.

183. Mørk A, Montezinho LP, Miller S, et al. Vortioxetine (Lu AA21004), a novel multimodal antidepressant, enhances memory in rats. Pharmacol Biochem Behav. 2013; 105: 41-50.

184. du Jardin KG, Jensen JB, Sanchez C, Pehrson AL. Vortioxetine dose-dependently reverses 5-HT depletion-induced deficits in spatial working and object recognition memory: a potential role for 5-HT1A receptor agonism and 5-HT3 receptor antagonism. Eur Neuropsychopharmacol. 2014; 24(1): 160-171.

185. Adams W, Kusljic S, van den Buuse M. Serotonin depletion in the dorsal and ventral hippocampus: effects on locomotor hyperactivity, prepulse inhibition and learning and memory. Neuropharmacology. 2008; 55(6): 1048-1055.

186. Lehmann O, Bertrand F, Jeltsch H, et al. 5,7-DHT-induced hippocampal 5-HT depletion attenuates behavioural deficits produced by 192 IgG-saporin lesions of septal cholinergic neurons in the rat. Eur J Neurosci. 2002; 15(12): 1991-2006.

187. Lehmann O, Jeltsch H, Lazarus C, Tritschler L, Bertrand F, Cassel JC. Combined 192 IgG-saporin and 5,7-dihydroxytryptamine lesions in the male rat brain: a neurochemical and behavioral study. Pharmacol Biochem Behav. 2002; 72(4): 899-912.

188. Lehmann O, Jeltsch H, Lehnardt O, Pain L, Lazarus C, Cassel JC. Combined lesions of cholinergic and serotonergic neurons in the rat brain using 192 IgG-saporin and 5,7-dihydroxytryptamine: neurochemical and behavioural characterization. Eur J Neurosci. 2000; 12(1): 67-79.

189. Murtha SJ, Pappas BA. Neurochemical, histopathological and mnemonic effects of combined lesions of the medial septal and serotonin afferents to the hippocampus. Brain Res. 1994; 651(1-2): 16-26.

190. Volpe BT, Hendrix CS, Park DH, Towle AC, Davis HP. Early post-natal administration of 5,7-dihydroxytryptamine destroys 5-HT neurons but does not affect spatial memory. Brain Res. 1992; 589(2): 262-267.

191. Gutierrez-Guzman BE, Hernandez-Perez JJ, Lopez-Vazquez MA, Fregozo CS, Guevara MA, Olvera-Cortes ME. Serotonin depletion of supramammillary/posterior hypothalamus nuclei produces place learning deficiencies and alters the concomitant hippocampal theta activity in rats. Eur J Pharmacol. 2012; 682(1-3): 99-109.

192. Richter-Levin G, Greenberger V, Segal M. The effects of general and restricted serotonergic lesions on hippocampal electrophysiology and behavior. Brain Res. 1994; 642(1-2): 111-116.

193. Kenton L, Boon F, Cain DP. Combined but not individual administration of beta-adrenergic and serotonergic antagonists impairs water maze acquisition in the rat. Neuropsychopharmacology. 2008; 33(6): 1298-1311.

194. Galani R, Berthel MC, Lazarus C, et al. The behavioral effects of enriched housing are not altered by serotonin depletion but enrichment alters hippocampal neurochemistry. Neurobiol Learn Mem. 2007; 88(1): 1-10.

195. Lieben CK, van Oorsouw K, Deutz NE, Blokland A. Acute tryptophan depletion induced by a gelatin-based mixture impairs object memory but not affective behavior and spatial learning in the rat. Behav Brain Res. 2004; 151(1-2): 53-64. 
196. Uchida S, Umeeda H, Kitamoto A, Masushige S, Kida S. Chronic reduction in dietary tryptophan leads to a selective impairment of contextual fear memory in mice. Brain Res. 2007; 1149: 149-156.

197. Dai JX, Han HL, Tian M, et al. Enhanced contextual fear memory in central serotonin-deficient mice. Proc Natl Acad Sci U S A. 2008; 105(33): 11981-11986.

198. Bert B, Dere E, Wilhelmi N, et al. Transient overexpression of the 5-HT1A receptor impairs water-maze but not hole-board performance. Neurobiol Learn Mem. 2005; 84(1): 57-68.

199. Bert B, Voigt JP, Kusserow H, Theuring F, Rex A, Fink H. Increasing the number of 5-HT(1A)-receptors in cortex and hippocampus does not induce mnemonic deficits in mice. Pharmacol Biochem Behav. 2009; 92(1): 76-81.

200. Wolff M, Costet P, Gross C, Hen R, Segu L, Buhot MC. Age-dependent effects of serotonin-1A receptor gene deletion in spatial learning abilities in mice. Brain Res Mol Brain Res. 2004; 130(1-2): 39-48.

201. Klemenhagen KC, Gordon JA, David DJ, Hen R, Gross CT. Increased fear response to contextual cues in mice lacking the 5-HT1A receptor. Neuropsychopharmacology. 2006; 31(1): 101-111.

202. Malá H, Arnberg K, Chu D, Nedergaard SK, Witmer J, Mogensen J. Only repeated administration of the serotonergic agonist 8-OHDPAT improves place learning of rats subjected to fimbria-fornix transection. Pharmacol Biochem Behav. 2013; 109: 50-58.

203. Winter JC, Petti DT. The effects of 8-hydroxy-2-(di-n-propylamino) tetralin and other serotonergic agonists on performance in a radial maze: a possible role for 5-HT1A receptors in memory. Pharmacol Biochem Behav. 1987; 27(4): 625-628.

204. Helsley S, Siegel TL, Fiorella D, Rabin RA, Winter JC. WAY-100635 reverses 8-OH-DPAT-induced performance impairment in the radial maze. Prog Neuropsychopharmacol Biol Psychiatry. 1998; 22(7): 1179-1184.

205. Egashira N, Yano A, Ishigami N, et al. Investigation of mechanisms mediating 8-OH-DPAT-induced impairment of spatial memory: involvement of 5-HT1A receptors in the dorsal hippocampus in rats. Brain Res. 2006; 1069(1): 54-62.

206. Inui K, Egashira N, Mishima K, et al. The serotonin1A receptor agonist 8-OHDPAT reverses delta 9-tetrahydrocannabinol-induced impairment of spatial memory and reduction of acetylcholine release in the dorsal hippocampus in rats. Neurotox Res. 2004; 6(2): 153-158.

207. Buhot MC, Patra SK, Naili S. Spatial memory deficits following stimulation of hippocampal 5-HT1B receptors in the rat. Eur $J$ Pharmacol. 1995; 285(3): 221-228.

208. Bauer EP. Serotonin in fear conditioning processes. Behav Brain Res. 2015; 277c: 68-77.

209. Youn J, Misane I, Eriksson TM, et al. Bidirectional modulation of classical fear conditioning in mice by 5 -HT(1A) receptor ligands with contrasting intrinsic activities. Neuropharmacology. 2009; 57(5-6): 567-576.

210. Hirst WD, Andree TH, Aschmies S, et al. Correlating efficacy in rodent cognition models with in vivo 5 -hydroxytryptamine1a receptor occupancy by a novel antagonist, (R)-N-(2-methyl-(4-indolyl1-piperazinyl)ethyl)-N-(2-pyridinyl)-cyclohexane carboxamide (WAY-101405). J Pharmacol Exp Ther. 2008; 325(1): 134-145.

211. McDevitt RA, Hiroi R, Mackenzie SM, et al. Serotonin 1B autoreceptors originating in the caudal dorsal raphe nucleus reduce expression of fear and depression-like behavior. Biol Psychiatry. 2011; 69(8): 780-787.

212. Wolff M, Savova M, Malleret G, Hen R, Segu L, Buhot MC. Serotonin 1B knockout mice exhibit a task-dependent selective learning facilitation. Neurosci Lett. 2003; 338(1): 1-4.

213. Malleret G, Hen R, Guillou JL, Segu L, Buhot MC. 5-HT1B receptor knock-out mice exhibit increased exploratory activity and enhanced spatial memory performance in the Morris water maze. J Neurosci. 1999; 19(14): 6157-6168.
214. Ahlander-Luttgen M, Madjid N, Schott PA, Sandin J, Ogren SO. Analysis of the role of the 5-HT1B receptor in spatial and aversive learning in the rat. Neuropsychopharmacology. 2003; 28(9): 1642-1655.

215. Fedotova YO, Ordyan NE. Blockade of 5-HT2A/2C-type receptors impairs learning in female rats in the course of estrous cycle. Bull Exp Biol Med. 2010; 150(1): 6-8.

216. Naghdi N, Harooni HE. The effect of intrahippocampal injections of ritanserin (5HT2A/2C antagonist) and granisetron (5HT3 antagonist) on learning as assessed in the spatial version of the water maze. Behav Brain Res. 2005; 157(2): 205-210.

217. Levin E, Icenogle L, Farzad A. Ketanserin attenuates nicotineinduced working memory improvement in rats. Pharmacol Biochem Behav. 2005; 82(2): 289-292.

218. Cohen H. Anxiolytic effect and memory improvement in rats by antisense oligodeoxynucleotide to 5-hydroxytryptamine-2A precursor protein. Depress Anxiety. 2005; 22(2): 84-93.

219. Zhang G, Ásgeirsdóttir HN, Cohen SJ, Munchow AH, Barrera MP, Stackman RW Jr. Stimulation of serotonin 2A receptors facilitates consolidation and extinction of fear memory in C57BL/6J mice. Neuropharmacology. 2013; 64: 403-413.

220. Tecott LH, Logue SF, Wehner JM, Kauer JA. Perturbed dentate gyrus function in serotonin 5-HT2C receptor mutant mice. Proc Natl Acad Sci U S A. 1998; 95(25): 15026-15031.

221. Burghardt NS, Bush DE, McEwen BS, LeDoux JE. Acute selective serotonin reuptake inhibitors increase conditioned fear expression blockade with a 5 -HT(2C) receptor antagonist. Biol Psychiatry. 2007; 62(10): 1111-1118.

222. Hodges H, Sowinski P, Sinden JD, Netto CA, Fletcher A. The selective 5-HT3 receptor antagonist, WAY100289, enhances spatial memory in rats with ibotenate lesions of the forebrain cholinergic projection system. Psychopharmacology (Berl). 1995; 117(3): 318-332.

223. Pitsikas N, Brambilla A, Borsini F. Effect of DAU 6215, a novel 5-HT3 receptor antagonist, on scopolamine-induced amnesia in the rat in a spatial learning task. Pharmacol Biochem Behav. 1994 47(1): 95-99.

224. Harrell AV, Allan AM. Improvements in hippocampal-dependent learning and decremental attention in 5-HT(3) receptor overexpressing mice. Learn Mem. 2003; 10(5): 410-419.

225. Segu L, Lecomte MJ, Wolff M, et al. Hyperfunction of muscarinic receptor maintains long-term memory in 5-HT4 receptor knockout mice. PloS one. 2010; 5(3): e9529.

226. Cachard-Chastel M, Devers S, Sicsic S, et al. Prucalopride and donepezil act synergistically to reverse scopolamine-induced memory deficit in C57Bl/6j mice. Behav Brain Res. 2008; 187(2): 455-461.

227. Orsetti M, Dellarole A, Ferri S, Ghi P. Acquisition, retention, and recall of memory after injection of RS67333, a 5-HT(4) receptor agonist, into the nucleus basalis magnocellularis of the rat. Learn Mem. 2003; 10(5): 420-426.

228. Fontana DJ, Daniels SE, Wong EH, Clark RD, Eglen RM. The effects of novel, selective 5-hydroxytryptamine (5-HT) 4 receptor ligands in rat spatial navigation. Neuropharmacology. 1997; 36(4-5): 689-696

229. Woolley ML, Bentley JC, Sleight AJ, Marsden CA, Fone KC. A role for 5-ht6 receptors in retention of spatial learning in the Morris water maze. Neuropharmacology. 2001; 41(2): 210-219.

230. Rogers DC, Hagan JJ. 5-HT6 receptor antagonists enhance retention of a water maze task in the rat. Psychopharmacology (Berl). 2001; 158(2): 114-119.

231. Stean TO, Hirst WD, Thomas DR, et al. Pharmacological profile of SB-357134: a potent, selective, brain penetrant, and orally active 
5-HT(6) receptor antagonist. Pharmacol Biochem Behav. 2002; 71(4): 645-654.

232. Lindner MD, Hodges DB Jr., Hogan JB, et al. An assessment of the effects of serotonin 6 (5-HT6) receptor antagonists in rodent models of learning. J Pharmacol Exp Ther. 2003; 307(2): 682-691.
233. Roberts AJ, Hedlund PB. The 5-HT(7) receptor in learning and memory. Hippocampus. 2012; 22(4): 762-771.

234. Gasbarri A, Cifariello A, Pompili A, Meneses A. Effect of 5-HT(7) antagonist SB-269970 in the modulation of working and reference memory in the rat. Behav Brain Res. 2008; 195(1): 164-170. 